\title{
OGRANICZENIA STANU JAKO PRZESZKODA W PRZYJMOWANIU DO KLASZTORÓW W CZASACH GRZEGORZA WIELKIEGO NA PODSTAWIE JEGO REGISTRUM EPISTULARUM ORAZ NORM PRAWA RZYMSKIEGO
}

Listy Grzegorza, obok Dialogów, ujawniają szczególny stosunek tego papieża do życia monastycznego. Bez wątpienia ma to związek z jego życiem, w którym miał miejsce pobyt w klasztorze. Wyjątkowe odniesienie do tego wymiaru życia ujawniają jego Dialogi z centralną postacią świętego Benedykta. Znajduje ono pełne potwierdzenie również w Listach, w których tematyka życia zakonnego jest jedną z głównych. O ile w stosunku do Dialogów posiadamy różne opracowania, to Listy nie są jeszcze w tym zakresie wystarczająco przebadane. Tymczasem jest to obszar niezwykle bogaty, zawierający takie mnóstwo informacji, że nie sposób usystematyzować ich $w$ formie choćby najobszerniejszej monografii. Publikacja niniejsza ma zatem na celu częściowe, jak na razie, podjęcie tematyki związanej z życiem monastycznym, które miało uprzywilejowane miejsce w sercu Grzegorza. Poświęcona ona będzie stosowanej przez papieża praktyce przyjmowania do klasztorów osób, w stosunku do których prawo wprowadzało ograniczenia ze względu na ich przynależność do określonych stanów społecznych.

\section{WPROWADZENIE}

1. Uwagi metodologiczne. Informacje, jakie posiadamy w Registrum Epistularum $^{1} \mathrm{~W}$ odniesieniu do zasad rekrutacji mnichów ${ }^{2}$, pozwalają dowiedzieć

${ }^{*}$ Ks. dr Janusz Lewandowicz - wykładowca języków klasycznych w Wyższym Seminarium Duchownym w Lodzi; e-mail: janlew@wsd.lodz.pl.

${ }^{1}$ Numeracja listów Grzegorza Wielkiego, jaką się posługuję, zasadniczo według wydania Norberga: S. Gregorii Magni, Registrum epistularum, Libri I-VII, CCL 140, Turnholti 1982; Libri VIII-XIV, Appendix, CCL 140A, Turnholti 1982. Wydanie to zostało przyjęte za podstawę dwujęzycznego - łacińsko-włoskiego wydania Listów w ramach wydania dzieł wszystkich Grzegorza w Città Nuova Editrice: Opere di Gregorio Magno, V: Lettere, a cura di V. Recchia, vol. 1-4, Roma 1996-1999. W obu tych wydaniach tekst łaciński i numeracja są identyczne.

${ }^{2}$ Spośród ogromnej literatury dotyczącej początków życia monastycznego w Italii i jego stanu 
się, jakie wymagania moralne i prawne stawiano kandydatom. Należy je odczytać i interpretować zwłaszcza w kontekście obowiązujących wówczas przepisów prawnych. Ich źródłem był przede wszystkim Codex Theodosianus wraz z późniejszymi Nowelami, a następnie Codex Iustiniani oraz jego Novellae. Dodatkowo wchodziły w grę normy będące reakcją władzy na aktualne problemy państwa w zakresie skutków wynikających z przechodzenia do życia mniszego. Idzie w tym przypadku o ustawy wydane przez cesarza Maurycjusza, których ślad nie zachował się w innych źródłach poza listami Grzegorza. Dla zrozumienia ducha ówczesnego prawodawstwa mają znaczenie również starsze normy, które zostaną przedstawione przy omawianiu poszczególnych zagadnień. Ich uwzględnienie pozwoli uchwycić również ewolucję prawodawstwa.

Licznie zakładane klasztory i propagowane przez Grzegorza życie zakonne związane były przede wszystkim z rozwijającym się dziedzictwem świętego Benedykta. Mówi się o nich jako o klasztorach benedyktyńskich. Trzeba jednak pamiętać, że nazwa ta nie oznacza koniecznego związania ich z Reguta świętego Benedykta. Dopiero bowiem od czasów karolińskich reguła ta stała się powszechnie obowiązującą normą dla zakładanych klasztorów³ ${ }^{3}$ Wcześniej życie monastyczne kształtowały reguły, jakie nadawali poszczególnym

w czasach Grzegorza Wielkiego zwracamy uwagę na pozycje najbliższe tematowi z zaznaczeniem, że w żadnej nie można znaleźć jego wyczerpującego opracowania: O. Porcel, La doctrina monastica di san Gregorio Magno y la „Regula Monachorum”, Madrid 1951; R. Rudmann, Mönchtum und kirchlicher Dienst in den Schriften Gregors des Großen, St. Ottilien 1956; C.M. Figueras, De impedimentis admissionis in religionem usque ad decretum Gratiani, Scripta et documenta 9, Abbatia Montisserrati 1957; G.D. Gordini, Origine e sviluppo del monachesimo a Roma, „Gregorianum” 37 (1956) 220-260; O. Porcel, San Gregorio y el Monacato. Cuestiones Controverdidas, Monastica 1, Scripta et Documenta 12, Abbatia Montisserrati 1960, 1-95; G. Jenal, Grégoire le Grand et la vie monastique dans l'Italie de son temps, w: Grégoire le Grand. Colloques Internationaux du Centre National de la Recherche Scientifique (Chantilly, Centre culturel Les Fontaines, 15-19 septembre 1982), ed. J. Fontaine - R. Gillet - S. Pellistrandi, Paris 1986, 147-157; F. Prinz, Das westliche Mönchtum zur Zeit Gregors des Grossen, w: Grégoire le Grand. Colloques Internationaux du Centre National de la Recherche Scientifique, s. 123-136; J. Leclercq, Spiritualità e Cultura nel Monachesimo del Pieno Medioevo, w: Cultura e Spiritualità nella Tradizione Monastica, ed. G. Penco, Studia Anselmiana 103, Rome 1990, 105-128; Gregorio Magno e il suo tempo. XIX Incontro di studiosi dellàntichità cristiana in collaborazione con l'Ecole Française de Rome (Roma, 9-12 maggio 1990), SEA 33, vol. 1-2, Roma 1991; G. Penco, Il monachesimo fra spiritualità e cultura, Milano 1991; tenże, Storia del monachesimo in Italia: dalle origini alla fine del Medioevo, Milano 20023; G. Jenal, In cerca di ordine quando l'apocalisse sembra vicina: Gregorio Magno e il monachesimo del suo tempo in Italia, w: Gregorio Magno nel XIV centenario della morte. Convegno internazionale (Roma, 22-25 ottobre 2003), Atti dei Convegni Lincei 209, Roma 2004, 221-246; P. Pellegrini, Militia clericatus monachici ordines: istituzioni ecclesiastiche e società in Gregorio Magno, Testi e studi di storia antica 20, Catania 2008²; B. Müller, Gregory the Great and Monasticism, w: A Companion to Gregory the Great, ed. B. Neil - M. Dal Santo, Leiden 2013, 83-108.

${ }^{3}$ Zwięzłe podsumowujące ujęcie zob. S. Pricoco, Introduzione, w: Gregorio Magno, Storie di santi e di diavoli, a cura di S. Pricoco - M. Simonetti, t. 1, Milano 2005, LI-LVII. 
klasztorom ich opaci. Zarówno Reguła Mistrza jak i Reguła świętego Benedykta $^{4}$ obok własnych zawierały ustalone tradycją elementy wspólne. W rekonstrukcji obrazu życia monastycznego w czasach św. Grzegorza obie te reguły są z tego względu bardzo przydatne ${ }^{5}$. Podstawowym jednak źródłem dla naszego tematu są Listy świętego Grzegorza oraz ustawodawstwo cesarskie - w szczególności Corpus Iustiniani. W prawodawstwie Justyniana przepisy dotyczące duchowieństwa zamieszczone zostały w tytule trzecim księgi pierwszej Kodek$s u$, gdzie znalazły się normy dotyczące mnichów. Miały one charakter stosunkowo ogólny, podczas gdy rozwinięte już życie monastyczne wymagało norm bardziej szczegółowych. Istotne regulacje przyniosły więc przede wszystkim nowela $\mathrm{V}^{6}$ i CXXIII $^{7}$. Nowela $\mathrm{V}$, poświęcona klasztorom, mnichom i przełożonym (De monachis), została wydana w roku 535. Nowela CXXIII dotyczyła życia kościelnego w szerszym zakresie i obejmowała reguły odnoszące się do biskupów, duchowieństwa i mnichów (De sanctissimis et Deo amabilibus et reverentissimis episcopis et clericis et monachis). Promulgowana została $\mathrm{w}$ roku 546, a więc już za życia Grzegorza. Ważnym prawem, uwzględnionym przez Justyniana, była nowela XXXV Walentyniana z roku $452^{8}$.

2. Zasady ogólne dotyczące przyjmowania do klasztorów. W czasach Grzegorza, zgodnie z postanowieniami noweli V, do klasztoru mógł wstapić każdy - bez względu na to, czy był człowiekiem wolnym czy niewolnikiem ${ }^{9}$. Ustawa cesarska nie określała wieku kandydatów. Górnej granicy wieku nie określały również żadne inne przepisy. Jeśli zaś chodzi o dolną granicę wieku, to na wychowanie do życia zakonnego w niektórych klasztorach przyjmowano już dzieci. Pośrednie świadectwo o tym znajdujemy w noweli VI Justyniana z 535 r., która wspomina o fakcie zmiany przynależności do stanu urzędniczego wskutek zaliczenia kogoś w wieku dziecięcym do wspólnoty klasztornej ${ }^{10}$. Dialogi pozwalają stwierdzić, że zwyczaj przyjmowania dzieci do klasztorów nie był czymś wyjątkowym ${ }^{11}$. Praktyka ta bywała jednak w niektórych razach

${ }^{4}$ Obie te reguły w języku polskim zawdzięczmy wydaniu benedyktynów tynieckich: Reguta Mistrza. Reguła św. Benedykta, tłum. T.M. Dąbek - B. Turowicz, ŹM 40, Kraków 2006.

${ }^{5}$ Por. A. de Vogüé, La Règle du Maître et les Dialogues de s. Grégoire, RHE 61 (1966) 44-76; Pellegrini, Militia, s. 36.

${ }^{6}$ Por. Iustinianus, Novella V, ed. R. Schoell - G. Kroll, w: Corpus iuris civilis, vol. 3: Novellae, Berolini 1895, 28-35.

${ }^{7}$ Por. tamże CXXIII, ed. Schoell - Kroll, s. 593-625.

8 Por. Valentinianus III, Novella XXXV 3 (a. 452), ed. Th. Mommsen - P.M. Meyer, w: Theodosiani libri XVI cum constitutionibus Sirmondianis et Leges Novellae ad Theodosianum pertinentes, vol. 2, Berolini 1905, 143.

${ }^{9}$ Por. Iustinianus, Novella V 2, ed. Schoell - Kroll, s. 29-31.

${ }^{10}$ Por. tamże VI 1, 1, ed. Schoell - Kroll, s. 36: „Et neque ex officiali aut ex curiali veniat fortuna, nisi tamen ex novella aetate, secundum quod iam dispositum est, in monasterio constitutus fortuna liberetur".

${ }^{11}$ Por. Gregorius Magnus, Dialogi II 3, 14, ed. A. de Vogüé, SCh 251, Paris 1978, 150: „Coepere 
przez Grzegorza ograniczana. Dotyczyło to miejsc, w których okoliczności życia były szczególnie trudne, jak np. na niektórych wyspach. W tym przypadku jako warunek przyjęcia papież określał wiek kandydata na 18 lat ${ }^{12}$. Z podobną sytuacją ograniczenia dolnej granicy wieku spotykamy się w liście Grzegorza do Kandyda, kapłana udającego się do Galii. Papież chciał, aby Kandyd wykupił z niewoli młodych Anglów w wieku 17 lub 18 lat z przeznaczeniem do życia $\mathrm{w}$ klasztorach ${ }^{13}$.

W noweli V Justyniana życie monastyczne określone zostało jako via sa$\mathrm{cra}^{14} \mathrm{i}$ w związku z tym cieszyło się szczególnymi względami prawa. Przyjęcie do klasztoru formalnie następowało poprzez przywdzianie stroju mniszego ${ }^{15}$. Aktu przyjęcia dokonywał opat. Musiało być ono uwarunkowane uzyskaniem pozytywnej jego opinii po trzyletnim okresie. Próba obowiązywała każdego, niezależnie od tego, czy był człowiekiem wolnym czy niewolnikiem ${ }^{16}$. Czas ten przeznaczony był na studium słowa Bożego i wypróbowanie obyczajów ${ }^{17}$. Okres próby odbywał się pod okiem mistrza duchowego, któremu probant musiał być we wszystkim posłuszny. Świadectwo tego stanu rzeczy daje Grzegorz w Dia$\log a c h^{18}$. Kandydat obowiązany był w tym czasie nosić strój świecki i właściwą świeckim tonsurę ${ }^{19}$. Wraz ze strojem mniszym otrzymywał tonsurę zakonną.

etiam tunc ad eum Romanae urbis nobiles et religiosi concurrere, suos que ei filios omnipotenti Domino nutriendos dare. Tunc quoque bonae spei suas soboles Euthicius Maurum, Tertullus uero patricius Placidum tradidit. E quibus Maurus iuvenior, cum bonis polleret moribus, magistri adiutor coepit existere, Placidus vero puerilis adhuc indolis annos gerebat”; tamże II 33, 230: „Soror namque eius, Scolastica nomine, omnipotenti Domino ab ipso infantiae tempore dicata, ad eum semel per annum venire consueverat, ad quam vir Dei non longe extra ianuam in possessione monasterii descendebat".

${ }^{12}$ Por. tenże, Epistula I 48, CCL 140, 62-63: „Quia autem dura est in insulis congregatio monachorum, etiam pueros in eisdem monasteriis ante decem et octo annorum tempora suscipi prohibemus. Vel si qui nunc sunt, tua eos experientia auferat et in Romanam urbem transmittat. Hoc et in Palmaria aliis que insulis te per omnia volumus custodire". Palmaria - dzisiejsza Palmarola, należąca do wysp Morza Tyrreńskiego leżących naprzeciw Terraciny.

${ }^{13}$ Por. tamże VI 10, CCL 140, 378: ,,volumus ut dilectio tua ex solidis quos acceperit vestimenta pauperum, vel pueros Anglos qui sunt ab annis decem et septem, vel decem et octo, ut in monasteriis dati Deo proficiant, comparet".

${ }^{14}$ Iustinianus, Novella V pr., ed. Schoell - Kroll, s. 28.

${ }^{15}$ Strój mniszy można było przywdziać po trzyletnim okresie próby zarówno dla wolnych, jak i niewolników. Jeśli chodzi o historię stroju zakonnego, zob. M. Augé, L'abito monastico dalle origini alla Regola di S. Benedetto, „Claretianum” 16 (1976) 33-95.

${ }^{16}$ Por. Iustinianus, Novella V 2, ed. Schoell - Kroll, s. 29: „Sancimus igitur sacras sequentes regulas, eos qui singularem conversationem profitentur, non prompte mox a reverentissimis praesulibus venerabilium monasteriorum habitum percipere monachilem, sed per triennium totum (sive liberi forte sive servi sint) tolerare".

${ }^{17}$ Por. tamże.

${ }^{18}$ Por. Gregorius Magnus, Dialogi I 1, SCh 251, 6-7.

${ }^{19}$ Por. Iustinianus, Novella V 2, ed. Schoell - Kroll, s. 29: „nondum monachicum habitum promerentes, sed tonsura et veste eorum qui laici vocantur uti, et manere divina discentes eloquia”. 
Prawo nakładało jednocześnie na przełożonego obowiązek zbadania stanu cywilnego i prawnego, to znaczy ustalenia czy zainteresowany nie jest niewolnikiem, kolonem, osobą obarczoną zadaniami publicznymi albo małżonkiem ${ }^{20}$. Opat badał też, czy motywy wstapienia do klasztoru były szczere. Miało to na celu głównie wykluczenie przypadków ucieczki do klasztoru przed konsekwencjami prawnymi ewentualnych przestępstw oraz kierowania się racjami przeciwnymi duchowi życia zakonnego ${ }^{21}$. Zadaniem opata była również ocena, jaki jest stosunek adepta do otrzymywanych nauk i jak przyjmuje on napomnienia, które zmierzały do wypróbowania stałości i powagi kandydata ${ }^{22}$. Brano również pod uwagę ocenę kandydata przez pozostałych członków wspólnoty ${ }^{23}$.

Procedurę przyjęcia kandydata podjęło na nowo prawodawstwo Justyniana w noweli CXXIII:

„Jeśli ktoś pragnie wejść na drogę życia monastycznego, postanawiamy: Jeśli nie podlega ograniczeniom stanu (notus est quia nullae fortunae subiacet), to opat klasztoru po zbadaniu sprawy niech go obłóczy. Jeśli jednak nie jest człowiekiem znanym albo nie wiadomo, do jakiego należy stanu, niech przez trzy lata nie przywdziewa stroju zakonnego, ale przez wspomniany okres niech przełożony klasztoru zbada jego sposób życia"24.

Zasadniczo nie wnosi ona pod tym względem nic nowego. Potwierdza jednak dotychczasowe prawo.

Po przebytym pozytywnie okresie próby następowało formalne przyjęcie do wspólnoty. Praktyka tego przyjęcia była oparta na przepisach Justyniana, jednak według zaleceń Grzegorza tonsury nie wolno było udzielić według Grzegorza wcześniej niż po okresie dwuletniej próby:

„Nadto surowo wszystkim zakażcie, Czcigodny Bracie, by tych, których przyjmują do klasztoru, żadną miarą nie ważyli się postrzygać przed upływem dwuletniej próby. A przez ten czas należy pilnie badać ich życie i obyczaje, aby któryś z nich nie był niezadowolony z tego, czego chciał, albo nie godził się na to, co wybrał. Bo skoro niestosowną jest rzeczą niedoświadczonych

\footnotetext{
${ }^{20}$ Por. Pellegrini, Militia, s. 177.
}

${ }^{21}$ Por. Iustinianus, Novella V 2, ed. Schoell - Kroll, s. 29: ,reverentissimos eorum abbates requirere eos, sive liberi sint sive servi, et unde eis desiderium vitae singularis accesserit, et discentes ab eis, quia nulla maligna occasio ad hoc eos adduxit".

${ }^{22}$ Por. tamże: „experimento percipere eorum tolerantiam et honestatem”.

${ }^{23}$ Por. tamże: „optimos semet ipsos et tolerabiles aliis monachis et praesuli demonstrantes”.

${ }^{24}$ Iustinianus, Novella CXXIII 35, ed. Schoell - Kroll, s. 618: „Si quis autem ad monachicam vitam venire voluerit, iubemus, si quidem notus est quia nullae fortunae subiacet, abbas monasterii si perspexerit, schema ei praebeat. Si vero non cognoscitur aut cuilibet fortunae subiacet, intra tres annos non accipere eum schema monachocum, et intra memoratum tempus experiatur huius conversationem monasterii praesul", thum. własne. 
dawać ludziom do posługi, jak to mógłby ktoś powiedzieć, to o ile bardziej przykre jest przeznaczać do służby Bożej niewypróbowanych"25.

Prawo cesarskie tymczasem jako minimum ustalało okres trzyletni ${ }^{26}$. Podobnie sam Grzegorz wymagał, aby w stosunku do żołnierzy ubiegających się o przyjęcie do klasztoru, okres próby trwał trzy lata ${ }^{27}$.

Obłóczyny i tonsura pociągały za sobą konsekwencje prawne. Najważniejsza z nich było wyzwolenie ze stanu niewolniczego. Skutek ten nowela uzasadnia przejściem zarówno wolnych, jak i niewolników, bezpośrednio pod władzę pochodzącą z nieba (caeleste dominium), obejmującą wszystkich lu$\mathrm{dzi}^{28}$. Istnieje tu konsekwentny związek z przekonaniem wyrażonym we wstępie do noweli $\mathrm{V}$, że życie zakonne dzięki swojej regule ascetycznej cieszy się taką godnością i taką zażyłością z Bogiem, iż zmywa u mnicha wszelkie ludzkie zmazy i czyni go czystym, poddanym duchowej naturze, działającym według ducha i wyższym ponad myśli ludzkie ${ }^{29}$. Skutkiem tego nowego sposobu życia jest wyłączenie mnicha od podległości prawu świeckiemu (póki zachowuje regułę i styl życia monastyczny). Ustawodawca czyni w ten sposób możliwą jego ucieczkę od świata. Warto zwrócić również uwagę na to, że z noweli $\mathrm{V}$ wynika, iż w życiu klasztornym status zakonnika nie zależał od jego pochodzenia.

${ }^{25}$ Gregorius Magnus, Epistula X 9, CCL 140A, 835: „Praeterea monasteriis omnibus fraternitas vestra districtius interdicat ut eos quos ad convertendum susceperint, priusquam biennium in conversatione compleant, nullo modo audeant tonsorare. Sed hoc spatio vita moresque eorum sollicite comprobentur, ne quis eorum aut non sit contentus quod voluit, aut ratum non habeat quod elegit. Nam dum grave sit inexpertos hominum obsequiis sociari, quis possit dicere quanto sit gravius ad Dei servitium improbatos applicari?", tłum. J. Czuj: Św. Grzegorz Wielki, Listy, t. 3, Warszawa 1955, 14. Ks. J. Czuj stosuje numerację według wydania Listów w MGH Epistulae 1: Gregorii I papae Registrum epistolarum. Libri I-VII, ed. P. Ewald - L.M. Hartmann, Berolini 1891; MGH Epistulae 2: Gregorii I papae Registrum epistolarum. Libri VIII-XIV, ed. P. Ewald - L.M. Hartmann, Berolini 1899. Numeracja podawana przez nas opiera się na wydaniu krytycznym D. Norberga zob. nota 1.

${ }^{26}$ Por. Iustinianus, Novella V 2, ed. Schoell - Kroll, s. 29: „dum triennio tota vita permanserint”; tamże CXXIII 35, 6, ed. Schoell - Kroll, s. 618-619. Dla porównania Reguła św. Benedykta za minimum przyjmowała 1 rok; zob. Benedictus, Regula 58.

${ }^{27}$ Por. Gregorius Magnus, Epistula VIII 10, CCL 140A, 527.

${ }^{28}$ Por. Iustinianus, Novella V 2, ed. Schoell - Kroll, s. 29-30: ,sive liberi sint [...] sive servi, penitus non inquietari, migrantes ad commune omnium (dicimus autem caeleste) dominium; et arripiantur in libertatem".

${ }^{29}$ Por. tamże, ed. Schoell - Kroll, s. 28: „Conversationis monachilis vita sic est honesta, sic commendare novit deo ad hoc venientem hominem, ut omnem quidem humanam eius maculam detergat, purum autem declaret ac rationabili naturae decentem et plurima secundum mentem operantem et humanis cogitationibus celsiorem". Warto zwrócić uwagę na porównanie obu wersji językowych tego fragmentu zawartych w Nowelach. Pozwala to na doprecyzowanie niejednoznacznych określeń łacińskich. Sformułowanie conversationis monachilis vita ma swój odpowiednik w postaci

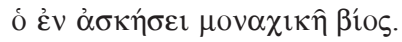


Ten, kto nosił się z zamiarem wstapienia do klasztoru, zanim to uczynił, mógł dowolnie dysponować swoimi rzeczami. Z chwila jednak, gdy został do klasztoru przyjęty, szły za nim również jego rzeczy, tak iż przestawał być ich posiadaczem nawet wówczas, gdy nie wyraził otwarcie, że wnosi je ze sobą do klasztoru ${ }^{30}$. Aby zostać mnichem należało mieć uregulowane zobowiązania finansowe ${ }^{31}$. Kto przywdział już strój mniszy, tracił prawo sporząadzania testamen$\mathrm{tu}^{32}$, a jego rzeczy przechodziły na własność klasztoru ${ }^{33}$. Klasztor przejmował mienie wstępującego, ale i jego długi. Jeśli mnich postanowił opuścić klasztor i powrócić do życia świeckiego, nie mógł zabrać ze sobą rzeczy, które wniósł wstępując do klasztoru, ani żadnych innych ${ }^{34}$.

Przyczyną wprowadzania ustaw mających na celu regulowanie rekrutacji zakonników i duchownych było zapobieżenie możliwemu zachwianiu funkcjonowania albo przynajmniej zmniejszeniu wydolności państwa. Bowiem migracja do stanu duchownego i życia zakonnego spowodowana przez rozwój chrześcijaństwa zyskała takie rozmiary, że zaczęła mieć istotne znaczenie zarówno dla ekonomii jak i obronności imperium. Wielu ludzi opuszczało swoje dotychczasowe życie i zajęcia, aby oddać się innemu życiu. Wszystko więc, co powodowało obniżenie produkcji, zwłaszcza rolnej, jak również zmniejszanie się wpływów podatkowych czy też obniżenie wydajności instytucji niewolnictwa albo militarnej wydolności państwa, uznawano za zagrożenie i dla władzy i dla jej poddanych. Zatem aby państwo mogło normalnie funkcjonować, ograniczano możliwość wstępowania w szeregi mnichów i duchownych. Jeśli idzie o tych ostatnich to przyjmowanie do ich grona regulowane było przepisami już od czasów Konstantyna ${ }^{35}$. Zainteresowanie prawodawców skupiało się najpierw na Egipcie i Azji Mniejszej, o czym świadczą wprowadzane ustawy obowiązujące najpierw na Wschodzie, a później aplikowane również w zachodniej części imperium.

Możliwość wstąpienia do klasztoru uwarunkowana była brakiem szczególnych zobowiązań wynikających z przynależności do określonego stanu

${ }^{30}$ Por. tamże V 5, ed. Schoell - Kroll, s. 32.

${ }^{31}$ Por. Gregorius Magnus, Epistula III 61, CCL 140, 209, thum. J. Czuj, t. 1, 242: „Dziwię się jednak bardzo, że w tymże prawie jest powiedziane, iż nie wolno mu wstapić do klasztoru, gdyż sprawy jego mogą być załatwione przez klasztor, i może się zdarzyć, że w miejscu, gdzie jest przyjęty, i jego zobowiązania zostają przyjęte. Boć przecież jeśliby ktoś chciał nawrócić się w pobożnym usposobieniu, pierwej musiałby zwrócić rzeczy źle nabyte, by tym prawdziwiej mógł myśleć o swej duszy, im jest swobodniejszy".

${ }^{32}$ Taką możliwość posiadał do momentu wstąpienia do klasztoru zgodnie z postanowieniami Iustinianus, Novella V 5 oraz CXXIII 38, ed. Schoell - Kroll, s. 32-33 i 621.

${ }^{33}$ Por. Gregorius Magnus, Epistula IX 198, CCL 140A, 755: „Quia ingredientibus monasterium conuertendi gratia ulterius nulla sit testandi licentia, sed res eorum eiusdem monasterii iuris fiant aperta legis definitione decretum est". Zob. tamże IV 6, CCL 140, 222-223.

${ }^{34}$ Por. Iustinianus, Novella V 4, ed. Schoell - Kroll, s. 32.

${ }^{35}$ Por. CTh XVI 2, 3, ŹMT 71 [wyd. łacińsko-polskie, oprac. M. Ożóg - M. Wójcik], Kraków $2014=\operatorname{SCL} 7,8$. 
społecznego, która była dziedziczna. Ogólnie rzecz biorąc przeszkoda wstapienia do klasztoru w związku ze stanem zachodziła w przypadku niewolników, kolonów, żołnierzy i urzędników państwowych. Można określić ich jako przeszkodzonych pochodzeniem i obowiązkami stanu (obnoxii). Należeli do nich ludzie wolni (kurialiści, kolonowie, przypisani do ziemi - adscripticii), a także niewolnicy ${ }^{36}$. Ograniczenia prawne dotyczące przyjmowania do klasztorów osób wywodzących się z określonych stanów społecznych dotyczyły najpierw kurialistów. Byli to ludzie posiadający pewien status majątkowy, który zobowiązywał ich do służby publicznej. Po nich przepisy obejmowały wszystkich związanych z uprawą ziemi i zarządem latyfundiami oraz niewolników ${ }^{37}$.

W układzie zasadniczo odpowiadającym temu porządkowi zostaną przedstawione przepisy prawne oraz treści korespondencji Grzegorza z tą różnicą że normy dotyczące kolonów i niewolników zostaną omówione razem ze względu na takie zgrupowanie ich w źródłach.

\section{OGRANICZENIA DOTYCZĄCE OSÓB WYWODZACCYCH SIĘ ZE STANU URZĘDNICZEGO}

Szybki rozwój chrześcijaństwa i jego popularność, pragnienie życia ewangelicznego i służby w szeregach duchowieństwa, zaczęły mieć tak znaczący wpływ na życie społeczne, że prowadziły do trudności w funkcjonowaniu społeczności lokalnych. Miało to znaczenie zwłaszcza w Egipcie, gdzie masowo wierni podejmowali życie monastyczne. Ciężar sprawy zaczął się ujawniać już za Konstantyna. Pierwszy akt ustawodawczy ograniczający swobodę wstępowania do stanu duchownego dotyczył dekurionów ${ }^{38}$. Dekurion to termin oznaczający urzędnika pełniącego funkcję radnego w radzie miasta. Samo słowo

${ }^{36}$ Osobną kategorię stanowiły osoby niepodlegające ograniczeniom dziedzicznym. Należeli do nich żołnierze oraz małżonkowie aktualnie związani węzłem. Problematyka dotycząca tych grup społecznych zostanie omówiona w oddzielnej publikacji.

${ }^{37}$ Istnieli także tacy, którzy tym ograniczeniom nie podlegali - in nullo obnoxii. Tymi, którzy nie podlegali wymienianym w ustawach ograniczeniom, byli ludzie wolni nieposiadający wystarczającego majątku do pełnienia funkcji publicznych oraz nieposiadający prawa obywatelstwa. Wyrażenie in nullo obnoxius znalazło się w trzeciej noweli Walentyniana z 439 r. Por. Valentinianus III, Novella III 4 (a. 439), ed. Mommsen - Meyer, vol. 2, s. 81.

${ }^{38}$ Trzy lata wcześniej, 21 lipca 317 r., Konstantyn określił zasady przynależności do kurii i wstępowania do stanu urzędniczego. Por. Constantinus, Constitutio XII 1, 5 (a. 326), ed. Mommsen - Meyer, vol. 2, s. 663: „Idem a. ad Bithynos. Eos qui in palatio militarunt et eos quibus provinciae commissae sunt quique merito amplissimarum administrationum honorem perfectissimatus vel egregiatus adepti sunt, nec non et illos, qui decuriones vel principales constituti cuncta suae patriae munera impleverunt, frui oportet dignitate indulta. Si vero decurio suffragio comparato perfectissimatus vel ducenae vel centenae vel egregiatus meruerit dignitatem declinare suam curiam cupiens, codicillis amissis suae condicioni reddatur, ut omnium honorum et munerum civilium discussione perfunctus iuxta legem municipalem aliquam praerogativam obtineat. Eum quoque, qui originis gratia vel incolatus vel ex possidendi condicione vocatur ad curiam, perfectissimatus suffragio impetra- 
oznacza osobę należącą do kurii, czyli instytucji skupiającej ciało kierownicze. Obok łacińskiego terminu decurio równolegle używano określenia curialis $^{39}$.

W 320 r. Konstantyn wydał konstytucję ${ }^{40}$ zabraniającą włączania w szeregi duchowieństwa dekurionów i ich dzieci. Funkcja kurialisty była bowiem dziedziczna. Na tym jednak nie poprzestał rozszerzając zakaz o wszystkich zdolnych do piastowania funkcji publicznych. Nakazał równocześnie, aby w miejsce zmarłych duchownych powoływać tylko tych obywateli, których szczupłość majątku nie obciąża koniecznością piastowania urzędów (muneribus civilibus $)^{41}$. Czasem jednak dochodziło do windykacji roszczeń o zobowiązania urzędnicze wobec tych, którzy weszli w szeregi duchowieństwa przed promulgacją zakazu. Konstantyn nie pozwalał ich więcej niepokoić. Tych jednak, którzy uchylając się (declinantes) od obowiązków publicznych uciekli (confugerunt) w szeregi duchowieństwa po ogłoszeniu ustawy, nakazuje wykluczyć z nich i oddać na powrót kurii i radom miejskim oraz zobowiązać do pełnienia obowiązków obywatelskich ${ }^{42}$. Powyższe prawo Konstan-

ti dignitas non defendit, qua remota tradi eum curiae oportebit. DAT. XII KAL. AUG. GALLICANO ET BASSO CONSS.".

${ }^{39}$ Por. np. B. Sitek, O ciężkiej doli decuriones w okresie późnego cesarstwa rzymskiego uwagi poczynione na podstawie wybranych konstytucji cesarskich, w: Procesy ujednolicenia prawa prywatnego w świetle integracji europejskiej, red. B. Ziemianin - B. Sitek - M. Tkaczuk, Szczecin 2001, 110: „Każde miasto miało swój senat - ordo decurionum, składający się zazwyczaj ze stu członków określanych mianem decuriones". Zob. także: A. Garino, Storia del rito Romano, Napoli 1996, 404; L. De Salvo, Munera curialia nel IV secolo. Considerazioni su alcuni aspelti sociali, w: Il tardo impero. Aspetti e significati nei suoi riflessi giuridici. X Convegno internazionale in onore di Arnaldo Biscardi (Spello - Perugia - Gubbio, 7-10 ottobre 1991), Napoli 1995, 291-318.

${ }^{40}$ Por. CTh XVI 2, 3, SCL 7, 8. Zob. uwagi francuskiego wydawcy dotyczące daty promulgacji ustawy: Les lois religieuses des empereurs romains de Constantin à Théodose II (312-438), vol. 1: Code théodosien - Livre XVI, ed. Th. Mommsen - R. Delmaire, SCh 497, Paris 2005, 126. Por. też Regesta pontificum Romanorum ab condita Ecclesia ad annum post Christum natum MCXCVIII (a. 416), ed. Ph. Jaffé - W. Wattenbach - S. Loewenfeld - F. Kaltenbrunner - P. Ewald, Leipzig 1885, vol. 1, 47, poz. 314 (111). Zob. J. Czuj, w: Św. Grzegorz Wielki, Listy, t. 1, s. 241, nota 5.

${ }^{41} \mathrm{~W}$ odniesieniu do problematyki dotyczącej relacji pomiędzy kuriami a miejscowymi Kościołami zob. R. Lizzi Testa, Come e dove reclutare i chierici? I problemi di Sant'Agostino, w: L'adorabile vescovo di Ippona. Atti del Convegno di Paola (24-25 maggio 2000), ed. F.E. Consolino, Soveria Mannelli 2001, 183-216.

${ }^{42}$ Por. CTh XVI 2, 3 (a. 320), SCL 7, 8: „Cum constitutio emissa praecipiat nullum deinceps decurionem vel ex decurione progenitum vel etiam instructum idoneis facultatibus adque obeundis publicis muneribus opportunum ad clericorum nomen obsequiumque confugere, sed eos de cetero in defunctorum dumtaxat clericorum loca subrogari, qui fortuna tenues neque muneribus civilibus teneantur obstricti, cognovimus illos etiam inquietari, qui ante legis promulgationem clericorum se consortio sociaverint. Ideoque praecipimus his ab omni molestia liberatis illos, qui post legem latam obsequia publica declinantes ad clericorum numerum confugerunt, procul ab eo corpore segregatos curiae ordinibusque restitui et civilibus obsequiis inservire. P(ro)p(osita) XV kal. aug. Constantino A. VI et Constantio Caes. conss". 
tyna znalazło uznanie również w oczach papieża Innocentego I (401-417) w $404 \mathrm{roku}^{43}$.

Następną regulacją było zarządzenie obu augustów - Walentyniana i Walensa - z 1 stycznia $370 \mathrm{r}^{44}$, zamieszczone w Kodeksie Teodozjusza (438). Odnosiło się do tych, którzy porzucili obowiązki (munera) państwowe i pod pozorem pobożności przyłączyli się do zgromadzeń mnichów w miejscach ustronnych i niedostępnych. Prawo to nakazuje komesowi Wschodu (per comitem Orientis) na terenie Egiptu (intra Aegyptum) pochwycić i wyrwać ich z owych kryjówek, a następnie przywrócić do służby publicznej, grożąc $\mathrm{w}$ przypadku nieposłuszeństwa utratą majątku ${ }^{45}$. Przepis ten został zamieszczony również w Kodeksie Justyniana (534), już jednak bez określeń ograniczających jego zasięg do wschodu i Egiptu ${ }^{46}$. Objął więc całe cesarstwo. Powyższe akty prawne miały za zadanie uniemożliwić ucieczkę urzędników państwowych od służby publicznej.

Sprawa nie została jednak rozwiązana definitywnie. Wielu chrześcijan musiało odczuwać zakaz wstępowania w szeregi duchowieństwa jako dotkliwy i niesprawiedliwy, skoro nieustannie podejmowali próby mimo nakładanych sankcji. Na Zachodzie w latach 439 i 452 Walentynian III, a po nim Majoran w 458 nadal wydawali ustawy ograniczające możliwość wstępowania w szeregi duchowieństwa. Według pierwszego postanowienia Walentyniana z 28 sierpnia $439 \mathrm{r}^{47}$ wszyscy, którzy jako kurialiści zobowiązani byli do służby publicznej, otrzymali zakaz przyjmowania posług kościelnych. Cel zarządzenia, jak się można było spodziewać, był finansowy: ut fiscales necessitates numerositate municipum facilius inpleantur. Jeśli jednak czyjaś pobożność skłaniała go, aby zostać duchownym wbrew postanowieniom prawa, tzn. zanim wypełnił obowiązki wobec państwa, to taką sytuację przewidywała nowela III Walentyniana. Był zmuszony wówczas ponieść stosowne konsekwencje. Przede wszystkim musiał znaleźć zastępcę, który wypełniłby zobowiązania państwowe zamiast niego. Mógł nim być syn, krewny lub współobywatel. Po

${ }^{43}$ Por. Innocentius I, Regestum 286, 13 (a. 404), ed. Ph. Jaffé - W. Wattenbach - S. Loewenfeld - F. Kaltenbrunner - P. Ewald, w: Regesta pontificum Romanorum ab condita Ecclesia ad annum post Christum natum MCXCVIII, vol. 1, 44: „curiales ne fiant clerici”.

${ }^{44}$ Inna możliwa data to rok 373. Por. CTh XII 1, 63, ed. Th. Mommsen - P. Meyer - P. Krueger - R. Delmaire, SCh 531, Paris 2009, 309.

${ }^{45}$ Por. tamże, s. 306-308: „Idem AA. ad Modestvm p(raefectvm) p(raetori)o. Quidam ignauiae sectatores desertis ciuitatum muneribus captant solitudines ac secreta et specie religionis cum coetibus monazonton congregantur. Hos igitur atque huiusmodi intra Aegyptum deprehensos per comitem Orientis erui e latebris consulta praeceptione mandauimus atque ad munia patriarum subeunda reuocari aut pro tenore nostrae sanctionis familiarium rerum carere illecebris, quas per eos censuimus uindicandas, qui publicarum essent subituri munera functionum. P(ro)p(osita) Beryto kal. ian. Val(entini)ano et Valente AA. conss".

${ }^{46}$ Por. SCh 531, 306-307, nota 2.

${ }^{47}$ Por. Valentinianus III, Novella III, ed. Mommsen - Meyer, vol. 2, s. 80-81. 
spełnieniu tego warunku mógł przyjąć urząd w Kościele. Zobowiązany był jednak wówczas do sądownego podzielenia majątku w równych częściach pomiędzy dzieci, z prawem zachowania jednej części dla siebie. Jeśli dzieci nie miał, dwie trzecie majątku musiał oddać krewnym, na których spoczywał obowiązek kurialny. Trzecią częścią mógł zadysponować dowolnie. Wolność w wyborze stanu duchownego posiadali jedynie ci, których majątek nie przekraczał trzystu solidów. W przeciwnym razie, poza pewnymi wyjątkami, posiadacz był automatycznie na podstawie cenzusu majątkowego zaliczany do grona kurialistów ${ }^{48}$.

Prawo inaczej traktowało tych, którzy chcieli zostać zakonnikami i tych, którzy chcieli wstąpić do stanu duchownego. Mnich bowiem, w odróżnieniu od przyjmującego święcenia, musiał się całkowicie wyrzec majątku. Jak ważne było to dla Grzegorza, świadczy jego uwaga poczyniona o mnichu Konstancjuszu, kandydacie na opata klasztoru w Rawennie: ,gorliwie ciuła majątek, co najlepiej świadczy, że nie ma serca mniszego"49.

Decyzja o przywdzianiu stroju pociągała za sobą w przypadku kurialistów rezygnację z możliwości dysponowania znacznymi dobrami materialnymi, jakie posiadali, skoro byli zobowiązani do służby publicznej. Ci, którzy decydowali się na stan duchowny, tracili zobowiązania, ale mogli część majątku zachować. Z punktu widzenia prawodawcy pójście do klasztoru albo w szeregi duchowieństwa było traktowane jednakowo - jako ucieczka od obowiązków stanu. Istnieje jednak istotna różnica między jednym a drugim wyborem, który

${ }^{48}$ Por. tamże III 3-4, ed. Mommsen - Meyer, vol. 2, s. 80-81: „In futurum vero ad ecclesiastica ministeria curialem suscipi praesenti lege prohibemus, ut fiscales necessitates numerositate municipum facilius inpleantur. Si quis sane ad clericatus obsequium etiam contra legum vetita animi devotione properaverit, si propriae non conpleverit onera civitatis, universa per suffectum reddere conpellitur: simili legis observatione facultates suas, sicut supra scriptum est, aut cum filiis aut cum propinquis aut cum patria divisurus. Quod si expletis muniis sacrosanctae religionis fuerit ministerio coniunctus, facultates suas viritim filiis distribuere per iudicem mox cogetur, sibimet virilem portionem inter liberos servaturus. Qui si liberos non habuerit, duas partes patrimonii sui propinquis, qui tamen curialitatis oneribus obnoxii sunt, absque ullo inminutionis commento, sicut superius dictum est, sciat protinus conferendas, omnibus in medium deductis, quae post honorem clericatus in fraudem legis alienanda esse crediderit: tertiam cui voluerit proprio dispensaturus arbitrio. Quae nostram serenitatem temperasse humanitatis intuitu vetera legum constituta testantur, quibus omne patrimonium cedere ordini proprio curialis praeceptus est, quoties ad ministerium clericatus eligitur. Illam quoque partem dispositio nostra non praeterit, ut, quisquis civis vel incola deinceps in nullo obnoxius, cuius tamen substantia trecentorum solidorum non exuperet quantitatem, fuerit repertus, habeat adipiscendi clericatus liberam facultatem. Eum vero, cuius patrimonium maiore quam definivimus aestimatione censebitur, liceat curiae secundum vetera statuta sociari, exceptis his qui sacris scriniis nostris et agentum in rebus scholae militant et aliis qui continuatae militiae observatione desudant, ut multis provisionum generibus ordinum numerus suppleatur nec tamen desint ministri venerandae religionis obsequiis". Stan majątku zobowiązujący do służby kurialnej mógł się różnić w zależności od miasta. Zob. Sitek, O ciężkiej doli decuriones, s. 110, nota 6.

${ }^{49}$ Gregorius Magnus, Epistula XII 6, CCL 140A, 974, tłum. Czuj, t. 4, s. 144. 
skutkował uwolnieniem się od tych zobowiązań. Mnich wyrzekał się własnej woli oraz posiadanego majątku, podczas gdy duchowny zachowywał jedno i przynajmniej w znaczącej części drugie.

Motyw materialny z pewnością odgrywał w wielu przypadkach rolę. To z kolei musiało mieć również konsekwencje społeczne w tej postaci, że stan mniszy rekrutował się w większej części spośród biedniejszych niż w przypadku duchowieństwa świeckiego. Jednocześnie musiało to oznaczać, że w klasztorach pojawiali się ludzie o znacznie niższym statusie społecznym i stopniu wykształcenia niż w szeregach duchowieństwa. W takim razie klasztory mogły przyciagać raczej niewolników czy kolonów, jeśli uwzględniać motywację nie tylko religijną. Mimo wszystko u Grzegorza zachowały się świadectwa o tym, że i patrycjusze przywdziewali strój zakonny, do czego zresztą niektórych papież usilnie zachęcat ${ }^{50}$.

W duchu ograniczenia napływu kandydatów pochodzących z niższych warstw należy odczytywać drugą interwencję Walentyniana na Zachodzie, który w roku 452 wprowadził nowe przepisy dotyczące wstępowania do stanu duchownego. Był to rok następujący po Soborze w Chalcedonie, który, jak wiadomo, zakazał przyjmowania niewolników do klasztorów. Nowe przepisy Walentyniana zawierały charakterystyczne sformułowanie opisujące logikę ograniczenia: vinculum debitae condicionis ${ }^{51}$. Cesarz poszerzał w niej grono objętych zakazem i precyzował, kto jeszcze nie może zostać mnichem. Miała ona podać wyliczenie wszystkich kategorii osób, które nie mogą być przyjęte do stanu duchownego i życia zakonnego ${ }^{52}$. Na liście znaleźli się więc przypisani do ziemi (originarii, inquilini), niewolnicy (servi), kolonowie (coloni), kurialiści (curiales), poborcy podatkowi (aurarii), członkowie kolegium sewirów (civis collegiatus sevir ${ }^{33}$ ) i niewolnicy publiczni (publici servi). Zadaniem nowej regulacji było uniemożliwienie wyłamania się z dziedzicznej przynależności do swego stanu i obszaru przypisanych doń obowiązkowych zadań.

Trzecim aktem przedjustyniańskim regulującym przyjęcia $\mathrm{w}$ szeregi duchowieństwa na Zachodzie była nowela Majorana z 6 listopada 458 roku. Ogranicza ona dostęp do święceń diakonatu, prezbiteratu i episkopatu. Miała również na celu przeszkodzić ucieczkom ludzi ze stanu społecznego, w którym

${ }^{50}$ Por. tamże I 40, CCL 140, 46; tamże XII 6, CCL 140A, 974-977.

${ }^{51}$ Por. Valentinianus III, Novella XXXV 3 (a. 452), ed. Mommsen - Meyer, vol. 2, s. 143: „Nullus originarius inquilinus servus vel colonus ad clericale munus accedat neque monachis et monasteriis adgregetur, ut vinculum debitae condicionis evadat, non corporatus urbis Romae vel cuiuslibet urbis alterius, non curialis, non exprimario, non aurarius, civis collegiatus sevir aut publicus servus". Jest to nowela z 15 kwietnia 452 r.

52 Tekst ustawy trudny do pewnego określenia. W odniesieniu do wątpliwości zob. K.L Noetlichs, Das Kloster als „,Strafanstalt” im kirchlichen und weltlichen Recht der Spätantike, „Zeitschrift der Savigny-Stiftung für Rechtsgeschichte” 111 (1994) 29-30, nota 26.

53 Sevir Augustalis oznacza członka sześcioosobowego kolegium dla sprawowania kultu Augusta. Por. tamże. 
żyli. Mówiąc słowami ustawy, dotyczyła ona tych, którzy „nie chcą być tym, czym są z urodzenia" ${ }^{54}$. Można zatem wnioskować, że duch tej noweli odnosi się także do tych, którzy pragnęli być mnichami.

Ustawy Walentyniana III i Majorana miały na celu przywrócenie służbie państwowej niższego duchowieństwa poprzez jego powrót w szeregi kurialistów działających w radach miejskich. Duchowni wyższego stopnia - biskupi, prezbiterzy i diakoni - zmuszeni byli na podstawie tych ustaw do zrzeczenia się znacznej części majątku na rzecz swych zastępców w służbie państwowej. W ten sposób ustawodawca starał się zapewnić imperium dostateczną liczbę urzędników ${ }^{55}$.

Echem tych aktów ustawodawstwa państwowego były treści zawarte w dekretach papieża Gelazego (492-496), odnoszące się do niewolników i osób związanych z ziemią. Papież wyrażał obawę, że ich ucieczka do służby kościelnej i do klasztorów może zachwiać i czystością wiary i porządkiem społecznym. Nakazuje jednocześnie, aby jeśli takie osoby są zatrzymywane przez biskupów, prezbiterów, diakonów lub przełożonych klasztorów nie z zamiarem oddania ich właścicielom, ale włączenia ich do wspólnot kościelnych, dokonać ich zwrotu, chyba że właściciel wyrazi zgodę na ich zatrzymanie ${ }^{56}$. Wreszcie w listopadzie roku 531. Justynian w swoim kodeksie potwierdza dotychczasowe ustawy podtrzymując, że żaden członek kurii ani dworu nie może być biskupem ani prezbiterem ${ }^{57}$.

${ }^{54}$ Maioranus, Novella VII 7 (a. 458), ed. Mommsen - Meyer, vol. 2, s. 169: „qui nolunt esse quod nati sunt", tłum. własne.

${ }_{55}^{55}$ Por. Pellegrini, Militia clericatus, s. 179-180.

${ }^{56}$ Por. Gelasius I, Epistula 14 (a. 495), ed. A. Thiel: Epistulae Romanorum Pontificum genuinae et quae ad eos scriptae sunt a s. Hilaro usque ad Pelagium II, t. 1, Brunsbergae 1868, 370-371 [= Decreta Gelasii papae zachowane u Dionizego Mniejszego, dekret 14, PL 67, 306B-D = Concilium Romanum (494/495), Epistola Gelasii ad episcopos per Lucaniam, Britios et Siciliam, ŹMT 62 (=SCL 6), wyd. A. Baron - H. Pietras, Kraków 2011, 311-312]: „Generalis etiam querelae vitanda praesumptio est, qua propemodum causantur universi passim servos, et originarios dominorum iura possessionemque fugientes sub religiosae conversationis obtentu vel ad monasteria sese conferre, vel ad ecclesiasticum famulatum, cohibentibus quoque praesulibus indifferenter admitti. Quae modis omnibus est amovenda pernicies: ne per Christiani nominis institutum aut aliena pervadi, aut publica videatur disciplina subverti. Praecipue, cum nec ipsam ministerii clericalis hac obligatione fuscari conveniat dignitatem, cogaturque pro statu militantium sibi, conditioneque iurgari, aut videri (quod absit) obnoxia quibus sollicita competenter interdictione prohibitis. Quisquis episcopus, presbyter, diaconus, vel eorum qui monasteriis praeesse noscuntur, hujusmodi personas apud se tenentes non restituendas patronis, aut deinceps vel ecclesiasticae servituti, vel religiosis congregationibus putaverint applicandas, nisi voluntate forsitan dominorum sub Scripturae testimonio primitus absolutas, aut legitima transactione concessas: periculum se honoris proprii non ambigant, communionisque subituros, si super hac re cuiusquam verax nos querela pulsaverit. Magnis quippe studiis secundum beatum Apostolum praecavendum est, ne fides, et disciplina Domini blasphemetur".

${ }^{57}$ Por. CJ I 3, 52, 1, ed. P. Krueger, Berolini 1877, 53. 
Prawa Walentyniana i Walensa, później Teodozjusza i Justyniana, przypisują ucieczkę do klasztorów lenistwu (ignaviae). Wiadomo jednak, że zwłaszcza $\mathrm{w}$ okresie niepokojów związanych $\mathrm{z}$ wędrówką ludów, której jednym z pierwszych i zarazem wyjątkowo bolesnym aktem była bitwa pod Adrianopolem (378), cesarstwo potrzebowało niezwykle sprawnie działającej machiny urzędniczej do ściągania podatków ${ }^{58}$. Prowadzenie wojny, a tym samym zapewnienie bezpieczeństwa obywatelom uzależnione było przede wszystkim od zasobności skarbca. Skuteczna działalność urzędników oznaczała być albo nie być dla cesarstwa. W czasach wystudzenia życia intelektualnego w wymiarze powszechnym była to zarazem warstwa dysponująca wystarczającym wykształceniem do prowadzenia działań o charakterze administracyjnym ${ }^{59}$. Trudno dziwić się zapobiegliwości władzy dbającej, aby z tego szeregu zapewniającego jej funkcjonowanie, nie ubywało urzędników.

Działania Grzegorza odznaczają się zrozumieniem problemu i zmierzają do znalezienia kompromisu pomiędzy potrzebami życia Kościoła i państwa. Można jednak zaobserwować odmienne podejście papieża do tych, którzy chcą wstapić do stanu duchownego i do tych, którzy wybierają życie w klasztorze. $\mathrm{Z}$ dzisiejszego punktu widzenia nie jest to do końca zrozumiałe, gdyż istniejące w starożytności różnice między jedną a drugą formą życia obecnie w dużym stopniu się zatarły. W okresie wczesnochrześcijańskim były one jednak znaczne.

Echem wprowadzanych przepisów a zarazem ilustracją tego, jak Kościół wywiązywał się z obowiązków wobec władzy świeckiej, jest wymowny fragment listu Grzegorza z listopada 597 r. do podległych mu metropolitów i biskupów Sycylii w sprawie zasad określonych przez cesarza Maurycjusza:

„Gorąco też napominamy, aby tych, którzy są zmazani zajęciami świeckimi, nie przyjmowano pochopnie do kleru kościelnego, bo jeśli w stroju kościelnym nie żyją inaczej, niż żyli, w takim razie nie starają się uciec przed światem, lecz tylko szukają odmiany. A jeśli ludzie starają się wstąpić do klasztoru, nie należy ich żadną miarą przyjmować, dopóki przedtem nie zostaną zwolnieni ze służby publicznej" ${ }^{60}$.

Mimo tych słów, które wyrażają uległość postanowieniom Maurycjusza, uważał Grzegorz, że stan zakonny winien być uprzywilejowany.

${ }^{58}$ Por. P. Heather, Upadek Cesarstwa Rzymskiego, tłum. J. Szczepański, Poznań 2014, 453-461.

${ }^{59} \mathrm{Na}$ temat ówczesnej sytuacji społecznej i politycznej zob. np. Świat Bizancjum, t. 1: Cesarstwo Wschodniorzymskie 330-641, red. C. Morrisson, tłum. A. Graboń, Warszawa 2007, 20 51; oraz wspomniane interesujące studium Heathera, Upadek Cesarstwa, passim.

${ }^{60}$ Gregorius Magnus, Epistula VIII 10, CCL 140A, 527, thum. Czuj, t. 3, s. 20. 


\section{OGRANICZENIA DOTYCZĄCE KOLONÓW I NIEWOLNIKÓW}

Prawodawstwo najczęściej obejmowało jednocześnie te dwie kategorie ludzi, dlatego zostaną one omówione wspólnie. Wyrażenia condicioni obnoxii ${ }^{61}$, condicionem loci debentes $^{62}$, condicionem debere ${ }^{63}$, jakie napotykamy w korespondencji Grzegorza, pochodzą z terminologii prawnej ustaw cesarskich i oznaczają przynależność albo do stanu kolonów ${ }^{64}$ albo niewolników. W ogólnym znaczeniu termin condicio oznacza tyle, co servitus.

Kolonami byli ludzie podlegli instytucji prawnej (kolonatowi) stanowiącej ich trwałą i dziedziczną służebność wobec uprawy ziemi należącej do pana, któremu zobowiązani byli dostarczać daninę dzierżawną w pieniądzu lub w naturze. Związek z ziemią był tak ścisły, że prawo nie przewidywało jego zerwania ani wskutek sprzedaży ani jakiegokolwiek jej zbycia ${ }^{65}$. Wśród kolonów rozróżniano w prawie dwie ich kategorie ${ }^{66}$ : simplices i alieni iuris ${ }^{67}$. Tych ostatnich zwano również adscripticii i byli oni trwale przypisani do określonej ziemi, a nie tylko do zadania uprawy. Z konstytucji Teodozjusza II wydanej 15 grudnia 434 r., stanowiącej o prawie spadkowym dotyczącym m.in. zmarłych zakonników wynika, że adscripticii nierzadko szli do życia zakonnego ${ }^{68}$. Niosło to za sobą różne konsekwencje społeczne, w tym ekonomiczne.

\footnotetext{
${ }^{61}$ Por. Gregorius Magnus, Epistula II 31, CCL 140, 118; tamże IX 145, CCL 140A, 696.

${ }^{62}$ Tamże IV 21, CCL 140, 239.

${ }^{63}$ Tamże II 26, CCL 140, 112.

${ }^{64} \mathrm{Na}$ temat instytucji kolonatu zob. np. M. Marković, The Later Roman Colonate and Freedom, Philadelphia 1997.

${ }^{65}$ Por. A.M. Larraona - S. Goyeneche, De personis et iuribus personalibus, w: Cursus syntheticus iuris Romanorum ad ius canonicum et civile praecipuarum nationum perpetuo comparati, ed. A.M. Larraona - S. Goyeneche, liber 1, vol. 2, pars 1, Roma 1927, 260.

${ }^{66}$ Por. Figueras, De impedimentis, s. 5.

${ }^{67}$ Por. CTh V 17, 1-18, ed. Mommsen - Meyer, s. 238-240.

${ }^{68}$ Por. tamże V 3, 1, ed. Mommsen - Meyer, s. 220: „Si quis episcopus aut presbyter aut diaconus aut diaconissa aut subdiaconus vel cuiuslibet alterius loci clericus aut monachus aut mulier, quae solitariae vitae dedita est, nullo condito testamento decesserit, nec ei parentes utriusque sexus vel liberi, vel si qui agnationis cognationisve iure iunguntur vel uxor exstiterit, bona, quae ad eum pertinuerint, sacrosanctae ecclesiae vel monasterio, cui fuerat destinatus, omnifariam socientur exceptis iis facultatibus, quas forte censibus adscripti vel iuri patronatus subiecti vel curiali condicioni obnoxii clerici vel monachi cuiuscumque sexus relinquunt. Nec enim iustum est, bona seu peculia, quae aut patrono legibus debentur aut domino possessionis, cui quis eorum fuerat adscriptus, aut ad curias pro tenore dudum latae constitutionis sub certa forma pertinere noscuntur, ab ecclesiis detineri; actionibus videlicet competenter sacrosanctis ecclesiis reservatis, si quis forte praedictis condicionibus obnoxius aut ex gestis negotiis aut ex quibuslibet aliis ecclesiasticis actibus obligatus obierit: ita ut, si qua litigia ex huiusmodi competitionibus in iudiciis pendent, penitus sopiantur, nec liceat petitori post huius legis publicationem iudicium ingredi vel oeconomis aut monachis aut procuratoribus inferre molestiam, ipsa petitione antiquata, et bonis, quae relicta sunt, religiosissimis ecclesiis vel monasteriis, quibus dedicati fuerant, consecratis. DAT. XVIII. KAL. IAN. ARIOVINDO ET ASPARE COSS". Prawo to zostało promulgowane w 438 r. dla obu części imperium.
} 
Pojmowanie przez Kościół problemu niewolnictwa można by streścić stwierdzeniem wyjętym z listów Grzegorza, że z ludzie natury są wolni, ale prawo pogan poprzez przemoc wprowadziło instytucję niewolnictwa. Pójście do klasztoru umożliwiało wyzwolenie się z tego jarzma, które niezgodnie z naturą zostało na człowieka nałożone:

„Zbawiciel nasz, Stwórca całego stworzenia, raczył przyjąć ciało ludzkie, aby rozerwawszy krępujące nas pęta łaską swego Bóstwa przywrócić nas do pierwotnej wolności. Dlatego też zbawienie się dzieje, jeśli ludzie, których od początku natura wolnymi wydała, a prawo pogańskie poddało w jarzmo niewoli, wracają do wrodzonej im wolności dzięki dobrodziejstwu wyzwalającego" ${ }^{69}$.

Rozwój chrześcijaństwa dokonujący się na wielką skalę zwłaszcza od panowania Konstantyna stawiał władze kościelne i świeckie wobec problemu niewolników. Nie mogli oni swobodnie praktykować wiary wobec przeszkód wynikających z niewolnictwa albo przywiązania do ziemi. Przynależność do swego stanu mogła uniemożliwiać wiernemu np. wstąpienie do klasztoru. Prawo stając na gruncie ochrony ekonomicznej pozycji cesarstwa nie pozwalało niewolnikom i kolonom na swobodne wstępowanie do wspólnot zakonnych. Kwestię tę porusza już św. Augustyn ok. 400. r. w dziełku poświęconym życiu mniszemu. Jego 22. rozdział zatytułowano wymownie: Contra otiosos et verbosos, qui exemplo et verbo alios avocant a labore. Nie wszyscy, jak widać, udawali się do klasztoru z najczystszych pobudek.

„Teraz zaś zgłaszają się na tę służbę Bożą w klasztorach najczęściej niewolnicy, wyzwoleńcy, wyzwoleni i mający być wyzwoleni przez panów ze względu na nią; z życia na wsi albo rzemieślniczego, z plebsu - tym bardziej przydatni, im bardziej wykształceni. Jeśli ich nie dopuścić - tym większe przewinienie. Spośród takich bowiem wielu okazało się wielkimi i godnymi naśladowania. Dlatego bowiem i słabe wybrał Bóg, by zawstydzało mocne, i co głupie na świecie, aby zawstydzało mądrych; i [rzeczy] mało szlachetne i te których nie ma - jakby były, aby te, które są, okazały się bezużyteczne: aby żadne ciało nie chlubiło się wobec Boga (1Kor 1, 27-29). Ta zbożna i święta myśl sprawia, że nawet takich się dopuszcza, którzy nie mogą okazać się żadnym dowodem przemiany życia na lepsze. Nie wiadomo też czy z postanowienia służenia Bogu przyszli, czy też uciekając od życia w trudzie i niedostatku chcieliby bez troski być żywieni i odziewani, a ponadto doznawać zaszczytów ze strony tych, przez których zwykli być pogardzani i lekceważeni"70.

\footnotetext{
${ }^{69}$ Gregorius Magnus, Epistula VI 12, CCL 140, 380, thum. Czuj, t. 2, s. 183.

${ }^{70}$ Augustinus, De opere monachorum 22, PL 40, 568: „Nunc autem veniunt plerumque ad hanc professionem servitutis Dei et ex conditione servili, vel etiam liberti, vel propter hoc a dominis liberati sive liberandi, et ex vita rusticana, et ex opificum exercitatione et plebelo labore, tanto utique felicius quanto fortius educati: qui si non admittantur, grave delictum est. Multi enim ex eo numero vere magni et imitandi exstiterunt. Nam propterea et infirma mundi elegit Deus, ut confunderet for-
} 
Wkrótce Kościół zaczął formułować zasady postępowania w przypadku zgłoszenia się niewolnika do klasztoru. $Z$ czasem określało je zarówno prawo kościelne jak i świeckie. Jeśli niewolnik przybywał za zgodą patrona sprawa była oczywista. Problem pojawiał się wówczas, gdy zgłaszała się osoba o niewiadomym statusie prawnym. Jeden z kanonów przypisywanych synodowi w Toledo ${ }^{71}$ określał, że w przypadku wstąpienia do wspólnoty osoby o nieudokumentowanym pochodzeniu, nie należy dawać jej możliwości przywdziania stroju mniszego przez okres trzech lat. W tym okresie mógłby zgłosić się ktoś dochodzący swych praw do kandydata. Jeśli okazałoby się, że kandydatem tym jest niewolnik, wyzwoleniec lub kolon, był zobowiązany powrócić do swego prawowitego pana wraz z wniesionym przez siebie dobytkiem. Właściciel musiał jednak zobowiązać się, że nie będzie go karał. Jeżeli w trakcie okresu próby nikt nie zgłaszał ewentualnych praw, to po upływie trzech lat nie mógł już tego uczynić. Przysługiwał mu jedynie zwrot należących do niego rzeczy, które zostały wniesione przez kandydata ${ }^{72}$.

Odchodzenie wielu ludzi do życia zakonnego zarówno na Wschodzie, jak i na Zachodzie, w sytuacji politycznej cesarstwa było ustawicznym problemem, a brak prawa regulującego możliwość i zasady wstępowania do klasztorów stawał się coraz dotkliwszy. Sprawą zajął się zwołany w roku 451 Sobór w Chalcedonie. Cesarz Marcjan na VI. sesji domagał się, aby ojcowie przyjęli przepis w brzmieniu następującym:

„Nie mogą przyjmować jako mnichów do swoich klasztorów bez zezwolenia ich panów niewolników albo przypisanych ziemi”’33.

tia; et stulta mundi elegit, ut confunderet sapientes; et ignobilia mundi, et ea quae non sunt, tanquam sint, ut ea quae sunt evacuentur: ut non glorietur omnis caro coram Deo (1Cor 1, 27-29). Haec itaque pia et sancta cogitatio facit ut etiam tales admittantur, qui nullum afferant mutatae in melius vitae documentum. Neque enim apparet utrum ex proposito servitutis Dei venerint, an vitam inopem et laboriosam fugientes vacui, pasci atque vestiri voluerint, et insuper honorari ab eis a quibus contemni conterique consueverant. Tales ergo quoniam se quo minus operentur, de infirmitate corporis excusare non possunt; praeteritae quippe vitae consuetudine convincuntur; umbraculo malae disciplinae se contegunt, ut ex male intellecto Evangelio praecepta apostolica pervertere meditentur", tłum. własne.

${ }^{71}$ Por. Fragmenta sub titulo Conciliorum Toletanorum, cap. 5, Mansi III 1012. Nawet jeśli nie jest to kanon synodu odbytego w 400. roku, to z pewnością odpowiada treścią prawom formułowanym w VI w., o czym będzie mowa poniżej. Zob. Pellegrini, Militia clericatus, s. 177.

${ }^{72}$ Por. Fragmenta sub titulo Conciliorum Toletanorum, cap. 5, Mansi III 1012: „Si aliquis incognitus monasterium ingredi voluerit, ante triennium monachi habitus ei non praestetur. Et si intra tres annos, aut servus, aut libertus, vel colonus quaeratur a domino suo, reddatur ei cum omnibus quae attulit, fide tamen accepta de impunitate. Si autem intra triennium requisitus non fuerit, postea quaeri non potest; nisi sit tam longe quod inveniri non possit: sed tantum ea quae in monasterium adduxit, dominus servi recipiat". Bez względu na to, czy wspomniany fragment pochodzi z roku 400, czy też jest późniejszy, oddaje zasady, jakimi kierowano się w czasach Grzegorza. Zasady zawarte w powyższym kanonie zawiera również prawodawstwo Justyniana.

${ }^{73}$ Concilium Chalcedonense, actio VI, Mansi VII 174-175: „Sed neque potestatem habere 
Życzył sobie jednocześnie, aby prawo zostało określone przez Kościół, a nie było stanowione przez cesarza. Ostatecznie sobór na XV. sesji pod kanonem czwartym przyjął przepis w brzmieniu:

„W klasztorach nie wolno przyjmować na mnicha niewolnika bez zgody jego właściciela" ${ }^{\text {"4 }}$.

Termin servus bez watpienia rozumiany był tu w szerokim znaczeniu, a zatem dotyczył również kolonów ${ }^{75}$.

Już w następnym roku prawo soboru w Chalcedonie zostało przyjęte na Zachodzie przez Walentyniana III (425-455) w brzmieniu podanym w cytowanym już wyżej fragmencie ${ }^{76}$. W tekście tym wyliczono dokładnie kategorie osób objętych zakazem: originarii, inquilini, servi, coloni ${ }^{77}$. Przeszkoda przynależności do powyższych kategorii nie miała jednak charakteru absolutnego. Mógł od niej uwalniać pan, pod którego władzą znajdowała się każda z tych osób. Zakaz Walentyniana dotyczył bowiem tych, którzy samowolnie „chcą wyrwać się od zobowiązań stanu"78.

$\mathrm{Na}$ Wschodzie sytuacje takie musiały być na porządku dziennym, ponieważ w 484 r. Zenon przyznał panom prawo windykacji z klasztorów rolników przypisanych ziemi, którzy udali się tam wbrew woli swych panów ${ }^{79}$. O ile jednak do stanu duchownego nie wolno było pójść ograniczając się do zgody pana, tzn. bez dokonania pełnego aktu wyzwolenia (manumissio), o tyle udającym się do klasztorów taka możliwość przysługiwała. Wystarczyła sama zgoda właściciela, który jednak musiał pamiętać, że udzieliwszy jej nie może się już domagać powrotu związanego z jego ziemią pracownika, chyba że opuściłby klasztor i życie monastyczne ${ }^{80}$.

monachos suscipiendi in monasteriis suis servos, aut inscriptitios, præter voluntatem dominorum", tłum. własne.

${ }^{74}$ Concilium Chalcedonense (451) can. 4, ŹMT 24 [wyd. grecko-polskie, układ i oprac. A. Baron - H. Pietras, thum. T. Wnętrzak], Kraków 2001 = DSP 1, 228: „Nullum vero recipere in monasteriis servum obtentu monachi, praeter sui domini conscientiam".

${ }^{75}$ Por. Figueras, De impedimentis, s. 6 oraz L. de Tillemont, Mémoires pour servir a l'histoire écclésiastique des six premiers siècles, t. 15, Paris 1711, 695.

${ }^{76}$ Por. nota 51 (nullus originarius).

${ }^{77}$ Por. Valentinianus III, Novella XXXV 3, ed. Mommsen - Meyer, s. 143.

${ }^{78}$ Tamże: ,ut vinculum debitae condicionis evadat”, tłum. własne.

${ }^{79}$ Por. CJ I 3, 36, pr., ed. Krueger, s. 24: „Iubemus adscripticiorum creationes secundum veterem constitutionem, nisi dominorum possessionum, unde oriundi sunt, evidens concurrerit consensus, nullius penitus esse momenti, sed isdem fundorum dominis, qui faciendae creationi non sicut dictum est evidenter consenserint, ius proprium ad similitudinem ceterorum colonorum in suos adscripticios exercendi, tamquam si nulla creatio intercessisset, tribui facultatem. idemque hoc super illis quoque agricolis decernimus observari, qui cum essent adscripticiae nexibus condicionis conscripti, solitariam vitam videlicet appetentes quibuslibet sese monasteriis contra voluntatem dominorum fundorum duxerint offerendos".

${ }^{80}$ Por. tamże: „Servis, si dominorum fuerint voluntate muniti, solitariam vitam participandi 
Zachód nie pozostawał $\mathrm{w}$ tyle we wprowadzaniu zasad przyjętych na Wschodzie. Na synodzie rzymskim, odbytym w latach 494/495 za papieża Gelazego, wystapiono zdecydowanie przeciwko praktykom uciekania ze stanu niewolniczego do życia zakonnego pod pozorem „pobożnego nawrócenia”. Mogło to zagrażać istniejącemu wówczas porządkowi społecznemu, ale także samemu chrześcijaństwu. Przepis uzasadniono niebezpieczeństwem oskarżenia religii o powodowanie strat właścicieli niewolników oraz kolonów ${ }^{81}$. Efektem tego był wydany po inwazji Herulów pod wodzą Odoakra w 494 r. list Gelazego Necessaria rerum, nazwany później „dekretem Gelazego”. Potwierdził on zakaz przyjmowania niewolników i kolonów do klasztorów, nakazując przełożonym natychmiastowy ich zwrot i grożąc im ekskomuniką, jeśli nie wypełnią zarządzenia ${ }^{82}$.

Podobną argumentację znajdujemy w dokumencie Grzegorza z odbytego w Rzymie w 595 r. synodu. W dekrecie dla duchowieństwa podpisanym przez 23 biskupów ostatni ustęp odnosi się do przyjmowania do klasztorów. Zdecydowanie nie dominuje w nim kontekst ekonomiczny. Z tekstu wynika, że każdy, kto kieruje się szczerym motywem, winien uzyskać możliwość służenia Bogu w życiu zakonnym ${ }^{83}$.

Wiek szósty przyniósł ze sobą pewne złagodzenie przepisów. Justynian promulgując w 529 r. swój Kodeks uwzględniał dotychczasowe zarządzenia swych poprzedników. Pojawiło się tu znów wyrażenie nexus adscripticiae condicionis $^{84}$, wskazujące na ograniczenie związane z przynależnością do określonego stanu. Wkrótce jednak Justynian uznał dotychczasowe prawo za nie dość odpowiednie i nazbyt przeszkadzające pragnącym oddać się służbie Bożej. W noweli V, wydanej w 535 r., rok po Kodeksie (repetitae praelectionis), spotykamy się z przyzwoleniem na przyjmowanie do klasztorów zarówno niewolników jak i kolonów nawet bez zgody panów, o ile w ciągu trzyletniego okresu probacji kandydaci wykażą dobre intencje, a panowie nie będą mogli dowieść, że pójście do klasztoru było spowodowane ucieczką przed karą za niegodziwy postępek, jak np. kradzież. Ogólnie mówiąc prawo

\footnotetext{
licentia non denegetur, dum tamen eorum domini non ignorent, quod, si servis suis ad monasteriorum cultum migrandi tribuerint facultatem, eorundem servorum dominio, donec idem servi in eodem monachorum habitu duraverint, spoliandos: alioquin si relicta forte vita solitaria ad aliam se condicionem transtulerint, certum est eos ad servitutis iugum, quam monachicae professionis cultu evaserant, reversuros".

${ }^{81}$ Por. Concilium Romanum (494/495), Epistula Gelasii ad episcopos per Lucaniam, Britios et Siciliam 16, ŹMT 62 [wyd. łacińsko-polskie, układ i oprac. A. Baron - H. Pietras, thum. B. Frontczak], Kraków 2011 = SCL 6, 311-312.

${ }^{82}$ Zob. nota 56.

${ }^{83}$ Por. Gregorius Magnus, Epistula V 57*, ed. Ewald -Hartmann, t. 1, s. 362-367.

${ }^{84}$ Por. CJ I 3, 36, ed. Krueger, s. 24.
} 
Justyniana starało się nie stawiać przeszkód tym, którzy chcieli wstąpić do klasztoru. Możliwość wstąpienia dawało również niewolnikom ${ }^{85}$.

Początkowo niewolnik i ktoś, w stosunku do kogo nie można było ustalić jego stanu prawnego, podlegał trzyletniemu okresowi próbnemu w klasztorze. Jeśli w tym czasie zgłosiłby się pan niewolnika ubiegającego się o przyjęcie do wspólnoty i oświadczył, że jest to człowiek, który wbrew jego woli ucieka do życia zakonnego z motywów nieszczerych, należało zbadać sprawę. Motywami takimi mogła być według ustawy np. chęć ucieczki przed karą za przestępstwa. Mogło się również zdarzyć, że niewolnik ukradł rzeczy należące do jego pana. W przypadku, gdy zarzuty okazały się prawdziwe, właściciel miał prawo zabrać ze sobą niewolnika na powrót do służby wraz z rzeczami należącymi do niego, jeśli znajdowały się w klasztorze. W takim razie musiał jednak złożyć przysięgę, że nie będzie czynił krzywdy niewolnikowi ${ }^{86}$. Na panu ciążyło zobowiązanie udowodnienia, że ten, do którego pretensje zgłasza, jest jego niewolnikiem. Jeśli jednak wykazano, że kandydat będąc jeszcze na służbie u swego pana był człowiekiem posłusznym i godziwym, podobnie jak w klasztorze, mógł w nim pozostac ${ }^{87}$.

Prawo przewidywało jednak, że nawet przed upływem trzyletniego okresu próby niewolnik mógł pozostać w klasztorze. Miało to miejsce, gdy zgłaszający swe prawa do niewolnika nie mógł ich udowodnić, albo jeśli zachowanie kandydata było godne życia duchowego i towarzyszyło mu świadectwo, że w czasie służby u swego pana był człowiekiem skromnym i odznaczał się szlachetnym usposobieniem. Wówczas po zakończeniu okresu próby włączony był do grona mnichów i nie obejmowało go żadne prawo windykacji. Jeśli jednak okazałoby się, że wniósł do klasztoru rzeczy należące do swego pana, podlegały one zawsze zwrotowi ${ }^{88}$. Ustawa ta w swej wymowie uznaje możli-

${ }^{85}$ Por. Iustinianus, Novella V 2, pr., ed. Schoell - Kroll, s. 29: „Hinc autem nobis etiam de singulis monachis cogitandum est, quo convenit fieri modo, et utrum liberos solum aut etiam forte servos, eo quod omnes similiter divina suscipit gratia, praedicans palam quia, quantum ad dei cultum, non est masculus neque femina, neque liber neque servos: omnes enim in Christo unam mercedem percipere".

${ }^{86}$ Por. tamże, ed. Schoell - Kroll, s. 29-30: ,si quis [...] intra triennium veniat aliquem in servitutem trahens volentium et perdurantium, ut fierent monachi, et dicat, quia arripuit quasdam res, et propterea, recurrit ad monasterium: sancimus, eum non prompte agere, sed primo probare pro veritate, quia et servus est et pro furto forsan aut pro vita maligna aut vitiis pessimis fugerit quidem, propter suum vitium ad monasterium autem venerit. Et si quidem verax ostenditur, et apparuerit propter huiusmodi causam monachicam simulans conversationem aut propter turpitudinem vitae forte defugiens et non pro veritate sanctimonii habitum concupiscens, hunc reddi domino cum quibus forsan ampuit, si tamen haec etiam in monasterio fuerint; eum vero, qui dominus adprobatur, dare ei iusiurandum, quia nihil mali ei faciet, et suscipere atque reducere domi”.

${ }^{87}$ Por. tamże, ed. Schoell - Kroll, s. 30.

${ }^{88}$ Por. tamże, ed. Schoell - Kroll, s. 29-30: „Si vero is quidem, qui dicit se esse dominum, nihil tale probaverit, appareat «autem» is, qui in talibus accusatur, ex ipsa conversatione honestus ac mitis, et forte testimonium habeat aliorum, quia etiam apud dominum consistens disciplinatus fuit et honestatis amator, vel si nondum forte completum est triennii tempus, attamen etiam sic 
wość wewnętrznej przemiany człowieka. Można powiedzieć, że przepisy noweli uwierzytelniają ewentualność resocjalizacji i sankcjonują jej skutki.

W przypadku, gdyby dawny niewolnik chciał opuścić klasztor po okresie próby i po przyjęciu do stanu mniszego, pan zyskiwał prawo upomnienia się o niego i włączenia na powrót do grona służby ${ }^{89}$. Prawo nakazywało powrót do stanu niewolniczego. Uznawało przy tym, że nie jest to dla niego krzywdzące, skoro dopuścił się niegodziwości polegającej na opuszczeniu życia, które ma oddawać cześć Bogu ${ }^{90}$.

Po trzyletnim okresie próby uznany za godnego przyjęcia stanu mniszego miał pozostać w klasztorze. Po tym okresie ustawała możliwość dochodzenia prawa do niewolnika, nawet jeśli okazałby się w przeszłości człowiekiem prowadzącym złe życie ${ }^{91}$.

Justynian w 546 r. podjął na nowo sprawę procedowania w przypadku przyjęcia do klasztoru. Wyliczył tym razem, że szczególnemu badaniu intencji przez okres trzyletni podlegają niewolnicy, koloni i przypisani do ziemi:

„Jeśli w ciągu trzech lat pojawiłby się ktoś twierdząc, że jest on [kandydat - JL] albo jego niewolnikiem albo kolonem, albo przypisanym do ziemi albo, że jest to człowiek, który schronił się do klasztoru uciekając przed uprawą roli albo coś ukradł lub że jest obciążony jakąś inną winą, ma być zwrócony własnemu panu wraz z rzeczami, które wniósł do klasztoru, uzyskawszy wpierw pod przysięga zapewnienie, że nie spotka go nic złego ze strony pana. Jeśli jednak w ciagu trzech lat nikt w sprawie żadnej ze wspomnianych osób nie zjawi się, opat klasztoru po upływie trzyletniego okresu, jeśli uzna takiego człowieka za godnego, wówczas niech da mu strój [duchowny], i nikt niech go potem nie niepokoi w sprawie jego stanu, dopóki jednak żyje w klasztorze; co do rzeczy zaś, o których wiadomo, że wniósł je do klasztoru, niech będą w nienaruszonym stanie zwrócone temu, kto okazał się jego panem. Jeśli zaś ktoś ze wspomnianych osób opuści klasztor i będzie wiódł życie świeckie udając się do miasta czy też na wieś, ma powrócić do swego stanu"92.

maneat in venerabile monasterium, trahentium asperitate liberatus. Trienni vero semel expleto tempore, iudicatus quia monachica dignus est honestate, maneat in monasterio. Nequaquam enim damus licentiam ulli penitus perscrutari quae eius sunt, sed sive servus sive liber sit, manere eum in conversatione volumus. Nam etsi vitium in priori ab eo forte gestum est vita (humana enim natura quodammodo labitur ad delicta), attamen sufficit ad mediocrem purgationem peccatorum et ad virtutis incrementum triennalis temporis testimonium. Ea vero, quae rata sunt, etiamsi apud quoscumque inveniantur, modis omnibus reddantur prisco domino".

${ }^{89}$ Por. tamże, ed. Schoell - Kroll, s. 31.

${ }^{90}$ Por. tamże: ,Si vero servitii necessitatem effugiens temptaverit monasterium quidem relinquere, aliam autem vitae sectari figuram, licentiam damus domino et trahere eum et probanti fortunam inter servos habere. Non enim iniuriam patietur tantum ad verum servitium tractus, quantum ipse iniuriatus est dei culturam refugiens".

${ }^{91}$ Por. tamże.

${ }^{92}$ Tamże CXXIII 35, ed. Schoell - Kroll, s. 618-619: „Si quis autem ad monachicam vitam 
Za panowania Justyniana zatem niewolnicy, kolonowie i adscripticii uzyskali możliwość wstapienia do klasztoru pod warunkiem, że byli wolni od chęci ucieczki przed konsekwencjami czynów popełnionych w przeszłości ${ }^{93}$. Wprawdzie wobec wszystkich panowie mieli prawo windykacji, jednak tylko w przeciagu trzech lat i jeśli byli w stanie wykazać nieprawidłowość intencji. Było to istotne złagodzenie zakazów. Kodyfikacja Justyniana na Wschodzie została natychmiast przyjęta. Na Zachodzie możliwe to było dopiero po zwycięstwie Justyniana nad Ostrogotami w 553 r. Promulgacja ustaw odbyła się na prośbę papieża Wigiliusza. Prawo cywilne nie stawiało już na ostrzu noża przeszkód związanych z przynależnością do stanu niewolniczego albo kolonatu ${ }^{94}$.

Kanon Soboru w Chalcedonie i dekret Gelazego wskazuja, jaka była kościelna praktyka prawna. Reguła świętego Benedykta nie zawiera informacji o przyjmowaniu tego rodzaju osób do klasztoru. Światło na tę kwestię rzucają jednak listy świętego Grzegorza. Wśród nich szczególne miejsce zajmuje list z 5 lipca 595 r. zawierający postanowienia synodu rzymskiego ${ }^{95}$.

Trzeba pamiętać również, że odmowa zgody ze strony właściciela niewolnika na jego wstapienie do klasztoru nie była zjawiskiem rzadkim. Grzegorz w liście do subdiakona Piotra w Kampanii nakazuje wykupić niewolnicę (puellam) od obrońcy Feliksa. Pragnęła ona wstąpić do klasztoru, jednak nie mogła uzyskać zgody swego pana. W zaistniałej sytuacji papież zadecydował o pokryciu właścicielowi niewolnicy ewentualnych strat finansowych poniesionych wskutek odejścia jej do klasztoru ${ }^{96}$. Jakkolwiek ograniczenie miało

venire voluerit, iubemus, si quidem notus est quia nullae fortunae subiacet, abbas monasterii si perspexerit, schema ei praebeat. Si vero non cognoscitur aut cuilibet fortunae subiacet, intra tres annos non accipere eum schema monachicum, et intra memoratum tempus experiatur huius conversationem monasterii praesul. Et si intra triennium emerserit aliquis dicens aut servum aut colonum aut adscripticium suum hunc esse, aut etiam tamquam fugientem agriculturam aut quasi aliquid rapientem aut propter aliquam culpam in monasterium eum ingressum, proprio domino hunc restitui cum rebus quas probatur in monasterium introduxisse, iusiurandum primum quia nihil patietur a suo domino percipientem. Si autem intra triennium nullus quaesierit aliquam memoratarum personarum, abbas monasterii post transcursionem triennalis temporis, si talem virum dignum iudicaverit, tunc det ei schema, et nullus ei postea sit molestus pro fortuna, donec tamen in monasterio deget; res autem, quas in monasterium introduxisse videtur, illaesae domino reddantur. Si quis autem memoratarum personarum reliquerit monasterium et ad saecularem veniat vitam, aut in civitatibus aut in agris circumiens propriae fortunae tradatur", tłum. własne.

${ }^{93}$ Por. tamże V 2, pr., ed. Schoell - Kroll, s. 29.

${ }^{94}$ Por. Figueras, De impedimentis, s. 11.

${ }^{95}$ List ten nie znalazł się wydaniu Norberga zapewne jako dokument zawierający postanowienia synodu. Ważne jest jednak, że był on promulgowany przez Grzegorza. Por. Gregorius Magnus, Epistula V 57*, ed. Ewald - Hartmann, t. 1, s. 362-367.

${ }^{96}$ Gregorius Magnus, Epistula III 39, CCL 140, 184-185: „Praeterea quia Felix defensor puellam nomine Catellam habere dicitur, quae cum magnis lacrimis et vehementi desiderio habitum conversationis appetit, sed eam praefatus dominus suus converti minime permittit, proinde volumus ut experientia tua praefatum Felicem videat atque puellae eiusdem animum sollicite requirat. Et si ita cognoverit, pretium eiusdem puellae suo domino praebeat, et eam hic in monasterio dandam cum 
umocowanie we wcześniejszych ustawach (już kanon 4. soboru w Chalcedonie stwierdza, że ,w klasztorach nie wolno przyjmować na mnicha niewolnika bez zgody jego właściciela"97), to poniesione koszty tym bardziej świadczą, że w oczach Grzegorza życie monastyczne miało wyjątkową wartość.

Ostatnie lata VI w. to czas, w którym niewolnicy Kościoła masowo usiłowali wstępować do klasztorów. Sprawę rozpatrywał wspomniany synod rzymski w 595 r. Potwierdzono na nim trzyletnią probację w klasztorze przed przyjęciem habitu ${ }^{98}$. Rozstrzygnięcie obejmowało również kolonów, ponieważ papież pisze ogólnie o rodzinie (familia) Kościoła, która w przeważającej części składała się z kolonów ${ }^{99}$. W praktyce działań Grzegorza potwierdza się zasada przyjęta w prawodawstwie cesarskim, iż kolonowie, którzy opuścili klasztor byli zobowiązani do powrotu do dawnego stanu.

Mimo wszystkich ograniczeń papież starał się o to, by niewolnicy mieli możliwość wstępowania do klasztorów. Wspomniany synod w Rzymie pod jego przewodnictwem zaleca:

„Wiemy, że wielu z kościelnej rodziny dąży do służby Boga wszechmocnego, aby wolni od służby ludzkiej mogli oddać się służbie Bożej w klasztorach. Jeśli ich będziemy puszczać gromadnie, damy im sposobność ucieczki z włości przynależnych do prawa kościelnego. Jeśli zaś spieszących do służby Boga wszechmocnego nieostrożnie zatrzymywać będziemy, okaże się, że czegoś odmawiamy Temu, który dał wszystko. Przeto jest rzeczą konieczną, aby każdy, kto spod prawa służebności kościelnej pragnie poświęcić się służbie Bożej, odbył przedtem próbę w stroju świeckim, a jeśli jego obyczaje i postępowanie dadzą świadectwo dobremu pragnieniu, powinien bez żadnej zwłoki uzyskać zezwolenie na służbę Bogu wszechmocnemu w klasztorze, aby ten, kto pod Bożym posłuszeństwem pragnie oddać się surowszej służbie, był wolny od ludzkiej służby"100.

Wiadomo jednak, że w wielu przypadkach nie było szczerego motywu. Dlatego właśnie ustawodawstwo cesarskie, jak i sam Grzegorz podkreślają jego

personis gravibus domino auxiliante transmittat". Converti oznacza tyle, co habitum conversationis indui. Jak zaznacza Migne (PL 77, 637C): „habitu conversionis indui, sanctimonialem aut ancillam Dei fieri, idem est".

${ }^{97}$ Concilium Chalcedonense (451) can 4, DSP 1, 228: „Nullum vero recipere in monasteriis servum obtentu monachi, praeter sui domini conscientiam".

${ }^{98}$ Por. Gregorius Magnus, Epistula V 57*, ed. Ewald - Hartmann, t. 1, s. 365, thum. Czuj, t. 2, s. 154. Była to zasada przyjęta już w noweli Justyniana V 2 oraz CXXIII 35.

${ }^{99}$ Por. Gregorius Magnus, Epistula I 42, CCL 140, 49-56. Znajduje się tu odniesienie do mnichów ex familia ecclesiastica. Zob. Figueras, De impedimentis, s. 13; J. Chapman, St. Benedict and the sixth century, London 19296 $158-159$.

${ }^{100}$ Gregorius Magnus, Epistula V 57*, ed. Ewald - Hartmann, t. 1, s. 365, tłum. Czuj, t. 2, s. 154. Zob. nota 95 i 98. 
znaczenie. W Listach znajdujemy przykłady interwencji papieża w przypadkach, kiedy szczerość intencji nie była oczywista lub oczywista była nieszczerość.

W liście do Antemiusza, subdiakona Kampanii, z maja 599 r. ${ }^{101}$, Grzegorz nakazuje oddać pewnego młodzieńca, który miał stwierdzić publicznie, że nie podlega ograniczeniom stanu będąc człowiekiem wolnym, i wstąpił do klasztoru. Zbiegł on pewnemu właścicielowi okrętu, Gallusowi, który przywiózł go z Sycylii w celu uczenia się odeń języka. Kiedy właściciel ów ponownie udał się na Sycylię, został oskarżony przez funkcjonariuszy publicznych o nieprawne zabranie niewolnika ${ }^{102}$ i obciążony kaucją. Wprawdzie list nie wspomina, czy od wstapienia do klasztoru upłynął okres trzech lat, wiadomo jednak, iż przyjął już strój mniszy. Grzegorz decyduje mimo tego o wezwaniu niewolnika do Panormos (Palermo). Miano tam rozpatrzyć jego sprawę. Nakazuje oddać go do dyspozycji obrońcy Fantyna, aby zwrócić go w przypadku wyroku sądu stwierdzającego jego zobowiązania wynikające ze stanu.

Przykład powrotu do stanu niewolniczego przynosi list Grzegorza z marca 595 r. do diakona Cypriana, zarządcy majątku kościelnego na Sycylii. Jest to przypadek o charakterze dyscyplinarnym. Mnich wydalony uprzednio z klasztoru na pokutę (in paenitentia deputatus) ma powrócić do grona służby kościelnej, którą wykonywał przed wstapieniem do klasztoru. Należał on bowiem wcześniej do służby biskupa Misenum. Ten zaś dowiedziawszy się o jego postępkach postanowił odzyskać go i z powrotem wcielić do grona swej służby kościelnej. Papież wyraża na to zgodę uznając za pożyteczne, gdyż winny:

„odczuje jarzmo poddaństwa, którego będąc tam [tzn. w klasztorze - JL] mógł na stałe uniknąć, skoro wskutek upadku zerwał z życiem zakonnym"

Niewolnicy szukali różnych sposobów na obejście prawa, dla uzyskania wolności. Droga przez służbę w Kościele wydawała się stosunkowo prosta. Ciekawy przykład znajdujemy w liście Grzegorza z roku 599:

„pewien diakon dwóch swoich niewolników obdarował wolnością pod warunkiem, iż zostaną mnichami i pozostaną w tym samym, co on klasztorze. Zastrzegł sobie, że gdyby który z nich warunku nie dotrzymał, z powrotem pójdzie w jarzmo niewoli; a właśnie jeden $\mathrm{z}$ nich warunek ten całkowicie zlekceważył, opuścił lekkomyślnie klasztor i wstapił w szeregi duchownych świeckich. Przeto, Czcigodny Bracie, zbadajcie to szczegółowo, a jeśli przekonacie się, że tak jest — zajmijcie się tą sprawą tak godnie i z biskupią gorli-

${ }^{101}$ Por. tamże IX 145, CCL 140A, 696: „licet iam monachi habitum sumpserit”.

${ }^{102} \mathrm{Na}$ temat niewolników publicznych zob. N. Lenski, Servi publici in Late Antiquity, w: Die Stadt in der Spätantike - Niedergang oder Wandel? Akten des internationalen Kolloquiums (München, am 30. und 31. Mai 2003), hrsg. J.-U. Krause - Ch. Witschel, Stuttgart 2006, 335-357.

${ }^{103}$ Gregorius Magnus, Epistula V 28, CCL 140, 295, thum. Czuj, t. 2, s. 86. 
wością, aby ani tamten nie miał możności opuszczenia klasztoru, ani też wola dającego wolność nie mogła być pod pozorem jakiejś wymówki ominięta"104.

Nie można było zatem ,uciec” z klasztoru nawet pod pozorem podjęcia się służby duchownej w świecie.

Trud życia zakonnego nie ustępował często temu, jaki obciążał niewolnika. Toteż zdarzało się, że mnisi woleli powrót do swojego dawnego stanu. Bywały przypadki, że do poprzedniego sposobu życia pragnęli powrócić ludzie wolni. Kiedy jednak raz zostali włączeni do wspólnoty, opuszczenie jej nie było wcale sprawą łatwą. W maju roku $592^{105} \mathrm{w}$ liście do chartulariusza ${ }^{106}$ Stefana, urzędującego na Sycylii, Grzegorz interweniował w sprawie dwóch mnichów, którzy zbiegli z klasztoru św. Jerzego położonego w miejscowości Maratodis. Żyli oni po świecku, a jeden pojął nawet żonę. Papież nakazuje ściągnąć ich na powrót do klasztoru uznając, że nawet gdyby byli niewolnikami (vel si condicionem debuissent), to nie należy się zgodzić na zmianę przez nich sposobu życia:

„Sprzeciwiałoby się to Bogu, gdyby po osiagnięciu zaszczytu, jakim jest służba Boża wrócili do świeckiego życia i stroju"107.

Z przeprowadzonej analizy źródeł można wysnuć wniosek o istnieniu pewnego napięcia pomiędzy tendencją obecną w ustawodawstwie świeckim, akcentującym motyw ekonomiczny, a dążeniami papieża do ożywienia życia monastycznego. Napięcie to wynikało z rozmiarów, jakie przybrało zjawisko wstępowania do klasztorów. Zgłaszanie się kandydatów mogło być motywowane duchowo albo wynikać z chęci wyzwolenia się spod ograniczeń związanych z przynależnością do swego stanu. Ocena motywacji następowała w okresie probacji. Niezależnie jednak od motywów rozmiar zjawiska nie pozostawał bez znaczenia dla funkcjonowania politycznego i ekonomicznego imperium. Wspomniane napięcie nie było jednak motywem dominującym we wzajemnych relacjach między państwem i Kościołem. Zwraca uwagę raczej daleko idące zrozumienie dla intencji ustawodawcy ze strony władzy kościelnej i chęć stosowania przepisów wprowadzanych przez imperatorów.

${ }^{104}$ Tamże IX 108, CCL 140A, s. 660-661, thum. Czuj, t. 3, s. 143.

${ }^{105}$ Por. tamże II 26, CCL 140, s. 112-113.

${ }^{106}$ Termin chartularius jest częsty w korespondencji Grzegorza i jest zazwyczaj synonimem notariusza lub jakiegoś urzędnika wojskowego. Stefan w innym liście (V 38) został nazwany „marinarum chartularius". Por. Opere di Gregorio Magno, V: Lettere, vol. 1, s. 112-113, nota 3; tamże, s. 313, nota 1 . Chodzi w tym przypadku prawdopodobnie o zarządcę majątku publicznego na Sycylii; zob. PL 77, 768D, nota f.

${ }^{107}$ Gregorius Magnus, Epistula II 26, CCL 140, s. 112, thum. Czuj, t. 1, s. 141. 
THE LIMITATIONS OF STATUS AS AN OBSTACLE IN ADMISSION TO THE MONASTERIES DURING THE TIMES OF GREGORY THE GREAT BASED ON HIS REGISTRUM EPISTULARUM AND THE RULES OF ROMAN LAW

(Summary)

Monastic life, which development has been significantly contributed by St. Gregory the Great, has an important place in the history of Europe. This paper attempts to go back to the period of monasticism in the Late Antiquity, of which there are numerous testimonies in the epistles of St. Gregory the Great. Based on Registrum epistularum, the paper presents the practice of admitting to the monasteries candidates from different social backgrounds. Simultaneously, it discusses the evolution of the imperial law, from the reign of Constantine to the end of the sixth century, by concerning restrictions on the admission to the monasteries arising from the fact of belonging to the specific state (obnoxii): decurions, tax collectors, colonate, slaves assigned to the land. The paper highlights the concern of Pope Gregory I for those who join the monasteries as well as draw attention to the motives, which guided the emperors to make laws concerning the admission to the monasteries and the Gregory's attitude towards the secular law. The paper also draws attention to the efforts of the pope aiming at promoting the monastic life as the highest form of Christian life.

Key words: Gregory the Great, Registrum epistularum, letters, Roman law, monasticism, admission to the monasteries, obnoxii, tax collectors, coloni, adscripticii, slaves.

Słowa kluczowe: Grzegorz Wielki, Registrum epistularum, listy, prawo rzymskie, monastycyzm, przyjmowanie do klasztorów, obnoxii, poborcy podatkowi, kolonowie, przypisani do ziemi, niewolnicy.

\section{BIBLIOGRAFIA}

\section{Źródła}

Augustinus, De opere monachorum, PL 40, 547-582.

Concilium Chalcedonense (451), w: Dokumenty soborów powszechnych, [wyd. grecko-polskie], układ i oprac. A. Baron - H. Pietras, tłum. T. Wnętrzak, ŹMT 24 = DSP 1, Kraków 2001, 191-257.

Concilium Romanum (494/495), Epistula Gelasii ad episcopos per Lucaniam, Britios et Siciliam, w: Dokumenty synodów od 431 do 504 roku, [wyd. łacińsko-polskie], układ i oprac. A. Baron - H. Pietras, tłum. B. Frontczak, ŹMT 62 = SCL 6, Kraków 2011, 305-317.

Corpus iuris civilis, vol. 1: Institutiones, ed. P. Krueger; Digesta, ed. Th. Mommsen, Berolini 1889; vol. 2: Codex Iustinianus, ed. P. Krueger, Berolini 1877; vol. 3: Novellae, ed. R. Schoell - G. Kroll, Berolini 1895. 
Fragmenta sub titulo Conciliorum Toletanorum, Mansi III, Florentiae 1759, 1007-1014. Gregorius Magnus, Dialogi, ed. A. de Vogüé, SCh 251, Paris 1978.

Gregorius Magnus, Registrum epistularum, ed. P. Ewald - L.M. Hartmann, MGH Epistulae 1: Gregorii I papae Registrum epistolarum. Libri I-VII, Berolini 1891; ed. P. Ewald - L.M. Hartmann, MGH Epistulae 1: Gregorii I papae Registrum epistolarum. Libri VIII-XIV, Berolini 1899; ed. D. Norberg, CCL 140-140A, Turnholti 1982; tłum. J. Czuj: Św. Grzegorz Wielki, Listy, t. 1-4, Warszawa 1954-1955.

Regesta pontificum Romanorum ab condita Ecclesia ad annum post Christum natum MCXCVIII, ed. Ph. Jaffé - W. Wattenbach - S. Loewenfeld - F. Kaltenbrunner P. Ewald, vol. 1, Leipzig 1885.

Theodosiani libri XVI cum constitutionibus Sirmondianis et leges novellae ad Theodosianum pertinentes, ed. Th. Mommsen - P.M. Meyer, Berolini 1905, vol. 1-2; Codicis Theodosiani Liber Sextus Decimus, wyd. łacińsko-polskie, oprac. M. Ożóg - M. Wójcik, tłum. A. Caba, ŹMT 71 = SCL 7, Kraków 2014, lub Les lois religieuses des empereurs romains de Constantin à Théodose II (312-438), vol. 1: Code Théodosien - Livre XVI, ed. Th. Mommsen - R. Delmaire, SCh 497, Paris 2005.

\section{Opracowania}

Augé M., L'abito monastico dalle origini alla Regola di S. Benedetto, „Claretianum” 16 (1976) 33-95.

Biondi B., Il diritto romano cristiano, t. 1-3, Milano 1952-1954.

Chapman J., St. Benedict and the sixth century, London $1929^{6}$.

De Salvo L., Munera curialia nel IV secolo. Considerazioni su alcuni aspelti sociali, w: Il tardo impero. Aspetti e significati nei suoi riflessi giuridici. X Convegno internazionale in onore di Arnaldo Biscardi (Spello - Perugia - Gubbio, 7-10 ottobre 1991), Napoli 1995, 291-318.

Figueras C.M., De impedimentis admissionis in religionem usque ad decretum Gratiani, Scripta et documenta 9, Abbatia Montisserrati 1957.

Garino A., Storia del rito Romano, Napoli 1996.

Gordini G.D., Origine e sviluppo del monachesimo a Roma, „Gregorianum” 37 (1956) 220-260.

Gregorio Magno e il suo tempo. XIX Incontro di studiosi dellàntichità cristiana in collaborazione con l'Ecole Française de Rome (Roma, 9-12 maggio 1990), SEA 33, vol. 1-2, Roma 1991.

Heather P., Upadek Cesarstwa Rzymskiego, tłum. J. Szczepański, Poznań 2014.

JENAL G., Grégoire le Grand et la vie monastique dans l'Italie de son temps, w: Grégoire le Grand. Colloques Internationaux du Centre National de la Recherche Scientifique (Chantilly, Centre culturel Les Fontaines, 15-19 septembre 1982), ed. J. Fontaine R. Gillet - S. Pellistrandi, Paris 1986, 147-157.

JENAL G., In cerca di ordine quando l'apocalisse sembra vicina: Gregorio Magno e il monachesimo del suo tempo in Italia, w: Gregorio Magno nel XIV centenario della morte. Convegno internazionale (Roma, 22-25 ottobre 2003), Atti dei Convegni Lincei 209, Roma 2004, 221-246. 
LeclercQ J., Spiritualità e Cultura nel Monachesimo del Pieno Medioevo, w: Cultura e Spiritualità nella Tradizione Monastica, ed. G. Penco, Studia Anselmiana 103, Rome 1990, 105-128.

Lenski N., Servi publici in Late Antiquity, w: Die Stadt in der Spätantike - Niedergang oder Wandel? Akten des internationalen Kolloquiums (München, am 30. und 31. Mai 2003), hrsg. J.-U. Krause - Ch. Witschel, Stuttgart 2006, 335-357.

Lizzi Testa R., Come e dove reclutare i chierici? I problemi di Sant'Agostino, w: L'adorabile vescovo di Ippona. Atti del Convegno di Paola (24-25 maggio 2000), ed. F.E. Consolino, Soveria Mannelli 2001, 183-216.

Marković M., The Later Roman Colonate and Freedom, Philadelphia 1997.

Markus R.A., Grzegorz Wielki, thum. P. Nehring, Warszawa 2003.

Müller B., Gregory the Great and Monasticism, w: A Companion to Gregory the Great, ed. B. Neil - M. Dal Santo, Leiden 2013, 83-108.

NoetLichs K.L., Das Kloster als „,Strafanstalt” im kirchlichen und weltlichen Recht der Spätantike, ,Zeitschrift der Savigny-Stiftung für Rechtsgeschichte” 111 (1994) 18-40.

Pellegrini P., Militia clericatus monachici ordines: istituzioni ecclesiastiche e società in Gregorio Magno, Testi e studi di storia antica 20, Catania $2008^{2}$.

PENCo G., Il monachesimo fra spiritualità e cultura, Milano 1991.

Penco G., Storia del monachesimo in Italia: dalle origini alla fine del Medioevo, Milano $2002^{3}$.

Porcel O., San Gregorio y el Monacato. Cuestiones Controverdidas, Monastica 1, Scripta et Documenta 12, Abbatia Montisserrati 1960.

Porcel O., La doctrina monastica di san Gregorio Magno y la „Regula Monachorum”, Madrid 1951.

Prinz F., Das westliche Mönchtum zur Zeit Gregors des Grossen, w: Grégoire le Grand. Colloques Internationaux du Centre National de la Recherche Scientifique (Chantilly, Centre culturel Les Fontaines, 15-19 septembre 1982), ed. J. Fontaine - R. Gillet S. Pellistrandi, PARIS 1986, 123-136.

Rudmann R., Mönchtum und kirchlicher Dienst in den Schriften Gregors des Großen, St. Ottilien 1956.

Sitek B., O ciężkiej doli decuriones w okresie późnego cesarstwa rzymskiego uwagi poczynione na podstawie wybranych konstytucji cesarskich, w: Procesy ujednolicenia prawa prywatnego $w$ świetle integracji europejskiej, red. B. Ziemianin - B. Sitek M. Tkaczuk, Szczecin 2001, 109-123.

Świat Bizancjum, t. 1: Cesarstwo Wschodniorzymskie 330-641, red. C. Morrisson, tłum. A. Graboń, Warszawa 2007.

VogüÉ A. de, La Règle du Maître et les Dialogues de s. Grégoire, RHE 61 (1966) 44-76. 